\title{
Production and Potential Applications of Bioconversion of Chitin and Protein-Containing Fishery Byproducts into Prodigiosin: A Review
}

\author{
San-Lang Wang $1,2, * \oplus$, Van Bon Nguyen ${ }^{3, *} \mathbb{1}$, Chien Thang Doan ${ }^{1,4} \oplus$, Thi Ngoc Tran ${ }^{1,4}$, \\ Minh Trung Nguyen ${ }^{4}(\mathbb{D})$ and Anh Dzung Nguyen ${ }^{5}(\mathbb{D}$ \\ 1 Department of Chemistry, Tamkang University, New Taipei City 25137, Taiwan; \\ doanthng@gmail.com (C.T.D.); tranngoctnu@gmail.com (T.N.T.) \\ 2 Life Science Development Center, Tamkang University, New Taipei City 25137, Taiwan \\ 3 Institute of Research and Development, Duy Tan University, Danang 550000, Vietnam \\ 4 Department of Science and Technology, Tay Nguyen University, Buon Ma Thuot 630000, Vietnam; \\ nguyenminhtrung2389@gmail.com \\ 5 Institute of Biotechnology and Environment, Tay Nguyen University, Buon Ma Thuot 630000, Vietnam; \\ nadzungtaynguyenuni@yahoo.com.vn \\ * Correspondence: sabulo@mail.tku.edu.tw (S.-L.W.); nguyenvanbon@duytan.edu.vn (V.B.N.); \\ Tel.: +886-2-2621-5656 (S.-L.W.); Fax: +886-2-2620-9924 (S.-L.W.)
}

Academic Editors: Thea Magrone, Rodrigo Valenzuela and Maurizio Battino Received: 12 May 2020; Accepted: 11 June 2020; Published: 13 June 2020

\begin{abstract}
The technology of microbial conversion provides a potential way to exploit compounds of biotechnological potential. The red pigment prodigiosin (PG) and other PG-like pigments from bacteria, majorly from Serratia marcescens, have been reported as bioactive secondary metabolites that can be used in the broad fields of agriculture, fine chemicals, and pharmacy. Increasing PG productivity by investigating the culture conditions especially the inexpensive carbon and nitrogen $(\mathrm{C} / \mathrm{N})$ sources has become an important factor for large-scale production. Investigations into the bioactivities and applications of PG and its related compounds have also been given increased attention. To save production cost, chitin and protein-containing fishery byproducts have recently been investigated as the sole $\mathrm{C} / \mathrm{N}$ source for the production of $\mathrm{PG}$ and chitinolytic/proteolytic enzymes. This strategy provides an environmentally-friendly selection using inexpensive $\mathrm{C} / \mathrm{N}$ sources to produce a high yield of PG together with chitinolytic and proteolytic enzymes by $S$. marcescens. The review article will provide effective references for production, bioactivity, and application of S. marcescens PG in various fields such as biocontrol agents and potential pharmaceutical drugs.
\end{abstract}

Keywords: prodigiosin; Serratia marcescens; marine drugs; chitin; bioconversion

\section{Introduction}

Chitin and its derivatives have numerous applications in the fields of environment protection, fine chemistry, and pharmacy [1-11]. Fishery processing byproducts, such as shrimp and crab shells, shrimp heads, and squid pens, are the main sources of chitin and chitosan which are conventionally prepared via chemical pretreatments of acid demineralization and hot-alkali deproteinization $[1,5,9,11-16]$. Chitin, chitosan, colloidal chitin, and water soluble chitosan have commonly been used as the major carbon/nitrogen $(\mathrm{C} / \mathrm{N})$ sources for the isolation of strains producing chitinolytic enzymes and the production of chitinolytic enzymes by these isolated strains $[9,15-18]$. To cut down fermentation expenses, the inexpensive materials of shrimp heads, shrimp shells, crab shells, and squid pens have recently been evaluated as the sole $\mathrm{C} / \mathrm{N}$ sources for the production of bioactive compounds $[5,6,9,12-16,19-74]$. The recovery of chitin-containing fishery byproducts as the $\mathrm{C} / \mathrm{N}$ source 
not only solves the environmental protection problem but also decreases the production costs of chitin and its derivatives.

Pigments of microbial origin have received much more attention in recent studies due to their versatile applications in agriculture, food, cosmetics, textile, and pharmacy. The antimicrobial, anti-cancer, and anti-parasite bioactivities confer the bacterial pigments with the potential to be developed as pharmaceutical products [75-78]. The worldwide concern recently has been to extend inclination towards the use of natural materials in place of artificial ones because of several advantages including concerns over environmentally-friendly sustenance $[77,79]$. Consequently, the uses of bacterial pigments have expanded much more than synthetic pigments [80]. Prodiginines (PGs), a family of red microbial pigments, have received much attention because of their considerable bioactivities [59-61,79-150], including antimicrobial [79-97], antiparasitic [102-109], insecticidal [60,61,110-113], anti-cancer [59,97,114-147], anti-oxidant [145,146], anti-inflammatory [145,146], immunosuppressant [147], and algicidal [99,148-150] activities. The potential applications of PGs as natural dyes have also been infrequently investigated for their use in textiles [101,151-154], candles [155], and cosmetics [96].

PGs include prodigiosin (PG, 2-methyl-3-pentyl-6-methoxyprodiginine), undecylprodigiosin, metacycloprodigiosin, streptorubin B, and cycloprodigiosin [156-159] (Figure 1). Among PGs, PG is the first member which appears dark red and can be easily dissolved in organic solvents such as ethanol, methanol, and acetone [160-162]. The name of PG derived from Kraft in 1902. PG was first isolated in the 1920s, its structural features were identified in the 1930s, and structure elucidation was completed in the 1960s [163-166]. Serratia marcescens is the major source of PG production [59-62,81-214]. PGs are also produced by some other bacterial strains including Serratia rubidaea [154,177], Alteromonas rubra [178], Janthinobacterium lividum BR01 [179], Rugamonas rubra [180], Streptomyces longisporus ruber 100-19 [181], Streptomyces coelicolor [182], Streptomyces spectabilis BCC 4785 [105], Streptomyces fusant NRCF69 [91], Streptomyces sp. [106], Vibrio sp. C1-TDSG02-1 [116,118], Vibrio sp. KSJ45 [101], V. gazogenes [183], V. psychroerythrus [184], Pseudomonas magnesiorubra [185], P. putida KT2440 [188,189], Streptoverticillium sp. 26-1 [191], Streptoverticillium rubrireticuli [181], Pseudoalteromonas sp. [186], Pseudoalteromonas rubra [100], Actinomycetes [146,187], and a gene recombinant strain of Pseudomonas putida [185,189].

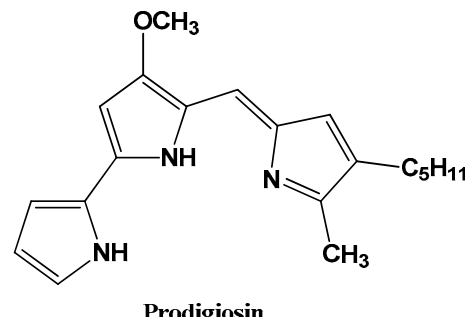

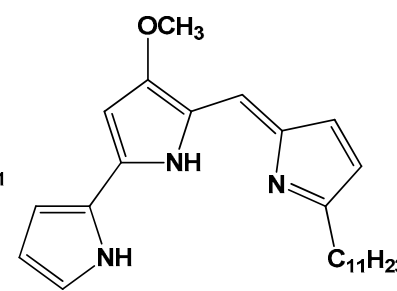

Undecylprodigiosin

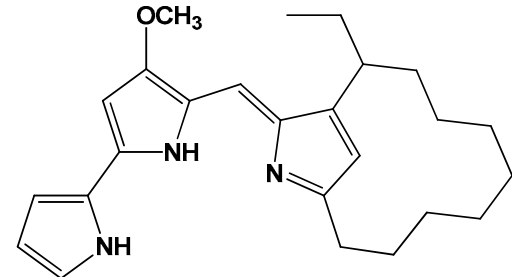

Metacyloprodigiosin

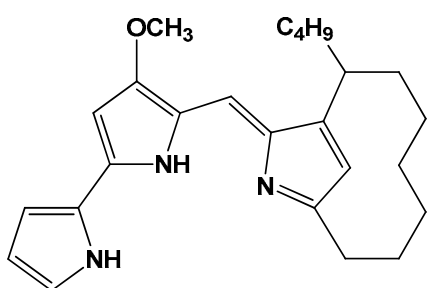

Streptorubin B

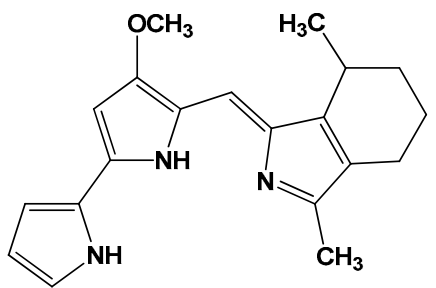

Cycloprodigiosin

Figure 1. Structures of prodigiosin, undecylprodigiosin, metacyloprodigiosin, streptorubin B, and cycloprodigiosin.

Some PG-related reviews reported the production of PG from S. marcescens using commercial media such as nutrient broth, peptone glycerol broth, and seed oils as the C/N sources $[156,161,162,166,168,171]$. The biological potentials of PG especially in the field of anticancer have also been reviewed [156-162, $166,168,169,171]$. For example, a review of the characteristics and potential therapeutic anticancer-drug applications of PG from Serratia was introduced by Darshan and Manonmani [180], while the 
structure, chemical synthesis, and biosynthesis of PGs as natural products were summarized by $\mathrm{Hu}$ et al. [157]. Additionally, synergistic inhibitory effects of chitinolytic enzymes [36,37,39,86-90], proteolytic enzymes [36,61,89,192-195], and S. marcescens PG were estimated for biocontrol in plant cultivation [85-90]. Biosurfactant produced by S. marcescens was also evaluated [167,196-198]. Recently, chitin and protein-containing marine byproducts have been utilized as the sole $\mathrm{C} / \mathrm{N}$ source by S. marcescens TKU011 for the simultaneous production of PG [59-62], chitinolytic enzymes, and proteolytic enzymes [36,37]. The present review discusses the foremost accomplishments in the production and isolation of $S$. marcescens $P G$, particularly the application of shrimp heads, shrimp and crab shells, and squid pens as C/N sources for PG production by S. marcescens TKU011 [59-62]. Additionally, the uses of $S$. marcescens PG in several fields, especially as biocontrol agents, are also comprehensively reviewed.

\section{Production of PGs}

PG produced by S. marcescens has been considered as a promising aim for drug development due to the described antifungal, immunosuppressive, and antiproliferative bioactivities. Hence, the culture conditions for large-scale production to ameliorate PG productivity becomes an essential issue [75-78,147]. To gain higher PG productivity, important factors for evaluation include the media composition, inorganic phosphate availability, temperature, and $\mathrm{pH}[199,200]$. In the case of $\mathrm{C} / \mathrm{N}$ source, the most commonly used media for PG production were commercial media, such as nutrient broth and peptone glycerol broth. For example, Giri et al. found that the PG productivity by $S$. marcescens was $520 \mathrm{mg} / \mathrm{L}$ and $569 \mathrm{mg} / \mathrm{L}$ in nutrient broth $\left(28^{\circ} \mathrm{C}\right)$ and peptone glycerol broth $\left(30^{\circ} \mathrm{C}\right)$, respectively [201]. Furthermore, the supplement of fatty acid-containing plant oils was found to show a positive effect on PG productivity which increased to $16,680 \mathrm{mg} / \mathrm{L}$ in sesame seed broth $\left(28^{\circ} \mathrm{C}\right)$ [201]. Kamble and Hiwarale reported that $S$. marcescens showed better PG productivity in nutrient broth than in peptone glycerol broth [173]. Regarding the use of agricultural byproducts as $\mathrm{C} / \mathrm{N}$ sources, ethanol and cassava wastewater were used for PG production by S. marcescens 389 [190], and S. marcescens UCP1549 [174], respectively. Further, chitin and protein-containing fishery byproducts have been utilized for PG production by S. marcescens TKU011 [59-62].

For the production of exopolysaccharides (EPS), Paenibacillus polymyxa EJS-3 has been reported to produce the highest EPS productivity $(35.26 \mathrm{~g} / \mathrm{L})$ by using sucrose $(188.2 \mathrm{~g} / \mathrm{L})$ and yeast extract $(25.8 \mathrm{~g} / \mathrm{L})$ as the $\mathrm{C} / \mathrm{N}$ source [56]. Recently, squid pens were utilized successfully to produce the highest yield of EPS from Paenibacillus sp. TKU023 (41.25 g/L) and P. macerans TKU029 (35.75 g/L) [56]. This inspired us to isolate the PG-producing strain, S. marcescens TKU011 using squid pens as the C/N source. The PG productivity of using chitin and casein, squid pens, shrimp shells, and shrimp heads as the sole C/N source by S. marcescens TKU011 was $4620 \mathrm{mg} / \mathrm{L}$ [59], $2480 \mathrm{mg} / \mathrm{L}, 190 \mathrm{mg} / \mathrm{mL}$, and $30 \mathrm{mg} / \mathrm{L}$, respectively [61].

Table 1 summarizes the comparison of the reported PG yield of $S$. marcescens by using different $\mathrm{C} / \mathrm{N}$ sources. Chen et al. reported that a $\mathrm{C} / \mathrm{N}$ ratio of $6 / 4$ of starch/peptone (1.6\% starch; $1.067 \%$ peptone) achieved a high PG yield $(6700 \mathrm{mg} / \mathrm{L})$ by S. marcescens C3. PG yield of $7070 \mathrm{mg} / \mathrm{L}$ was achieved after optimizing the concentrations of $\mathrm{FeSO}_{4} \cdot 4 \mathrm{H}_{2} \mathrm{O}(0.56 \mathrm{mM})$ and $\mathrm{MnSO}_{4} \cdot 4 \mathrm{H}_{2} \mathrm{O}(3.25 \mathrm{mM})$ [172]. Kamble and Hiwarale [173] studied S. marcescens PG production in peptone glycerol broth and nutrient broth and observed that the highest PG productivity was $1335 \mathrm{mg} / \mathrm{L}$ and $1845 \mathrm{mg} / \mathrm{L}$, respectively after three days of cultivation [173]. Different from most other studies, the enhancing effects of oil supplements on PG production were not observed in this study [173]. The comparison of PG productivity by $S$. marcescens $\mathrm{SR}_{1}$ in nutrient broth and glycerol-yeast extract media was evaluated by Parani and Saha [81]. The results showed that a higher PG productivity $(765 \mathrm{mg} / \mathrm{L})$ may be achieved by supplementation of $4 \%$ vegetable oil mixture (sunflower, coconut, and olive oil) [81]. Medium containing ethanol $(1.5 \%)$ and cottonseed meal $(1.5 \%)$ omitted inorganic salts (phosphate and $\mathrm{NaCl}$ ) and afforded S. marcescens S389 to produce up to $3000 \mathrm{mg} / \mathrm{L}$ PG [190]. Medium supplemented with powdered peanut, coconut, sesame, and castor seed was evaluated for PG production by S. marcescens 
PP1. The maximum yield of PG reached $1595 \mathrm{mg} / \mathrm{L}$ in powdered peanut-supplemented medium. Additionally, PG production by supplementing maltose and glucose to sunflower seed media reached $1556 \mathrm{mg} / \mathrm{L}$ and $1525 \mathrm{mg} / \mathrm{L}$, respectively [82]. Peptone (1\%) and maltose (0.5\%) were used as the C/N source by $S$. marcescenss subsp. lawsoniana HDZK-BYSB107 for the production of PG (656 mg/L), which showed antibacterial and antitumor activities [143].

Table 1. Comparison of prodigiosin (PG) yield by S. marcescens in different reports.

\begin{tabular}{|c|c|c|c|}
\hline Culture Medium & PG & Cultivation & Reference \\
\hline (C/N Source) & Productivity (mg/L) & Temp/pH/Time & \\
\hline Chitin/casein & 4620 & $30^{\circ} \mathrm{C} 1 \mathrm{Day} / 25^{\circ} \mathrm{C} 2$ Day & [59] \\
\hline Squid pens & 2480 & & [61] \\
\hline Shrimp shells & 190 & & {$[61]$} \\
\hline Shrimp heads & 30 & & [61] \\
\hline Crab shells & 110 & & [61] \\
\hline Ram horn peptone/mannitol & 277.74 & $48 \mathrm{~h}$ & [170] \\
\hline Peanut seed broth & 47,000 & - & [91] \\
\hline Peanut seed broth & 3875 & $28^{\circ} \mathrm{C} /-/ 36 \mathrm{~h}$ & [201] \\
\hline Peanut seed broth & 1595 & $28^{\circ} \mathrm{C}$ after $48 \mathrm{~h}$ & [82] \\
\hline Peanut oil & 2890 & & [201] \\
\hline Peanut powder/olive oil/beef extract & 13,622 & & [212] \\
\hline Sunflower seed broth/maltose & 1556 & & [82] \\
\hline Sunflower seed broth/glucose & 1525 & & [82] \\
\hline Sesame seed broth & 16,680 & $28^{\circ} \mathrm{C} /-/ 36 \mathrm{~h}$ & [201] \\
\hline Sesame oil & 1006 & & [201] \\
\hline Coconut oil & 1420 & & [201] \\
\hline Copra seed & 1940 & & [201] \\
\hline Casein-enriched broth/vegetable oil & 765.1 & $30{ }^{\circ} \mathrm{C} / 7 / 84 \mathrm{~h}$ & [81] \\
\hline Ethanol/cottonseed meal & 3000 & $28^{\circ} \mathrm{C} / 6.8 / 72 \mathrm{~h}$ & [190] \\
\hline Casein & 4280 & & [206] \\
\hline Cassava wastewater/mannitol & 49,500 & $28^{\circ} \mathrm{C} / 7 / 48 \mathrm{~h}$ & [174] \\
\hline Yeast extract & 690 & & [176] \\
\hline Yeast extract & 380.2 & & [212] \\
\hline Yeast/tryptone & 152 & $30^{\circ} \mathrm{C} / 72 \mathrm{~h}$ & [172] \\
\hline Nutrient broth/glycerol & & $25^{\circ} \mathrm{C} / 72 \mathrm{~h}$ & [169] \\
\hline Tryptone & 353 & & [212] \\
\hline Soya peptone & 1174 & & [212] \\
\hline Peptone/maltose & 656 & $28^{\circ} \mathrm{C} / 72 \mathrm{~h}$ & [143] \\
\hline Sweet potato powder/casein & 4800 & & [171] \\
\hline Soybean powder & 0 & & [212] \\
\hline Corn steep liquor & 0 & & [212] \\
\hline $\begin{array}{l}\text { Modified Luria-Bertani } \\
\text { broth/sunflower oil }\end{array}$ & 790 & & [175] \\
\hline 3-[N-morpholino]-Ethanesulfonic acid & 475 & & [199] \\
\hline
\end{tabular}

Cassava wastewater supplemented with $2 \%$ mannitol was used by S. marcescens UCP1549 to produce PG $(49,500 \mathrm{mg} / \mathrm{L})$ [174]. To avoid using individual fatty acid as a substrate for reducing the cost of industrial production, Giri et al. investigated the effect of different fatty acid-containing media for PG production and found that the higher yield was obtained in peanut seed medium $(38,750 \mathrm{mg} / \mathrm{L})$ and sesame seed broth $(16,680 \mathrm{mg} / \mathrm{L})$ [201]. Crude glycerol (a waste from biodiesel industry) was supplemented with peptone as a C/N source for PG production by S. marcescens MN5 [202]. Ram horn peptone $(0.4 \%)$ supplemented in mannitol medium showed enhanced PG production (277.74 mg/L) by S. marcescens MO-1 [170]. To decrease the medium cost by using tannery fleshing (TF) as a C/N source, the proteinaceous byproducts of leather industries, Arivizhivendhan et al. studied the PG production in TF $(30 \%, w / w)$ and wheat bran $(70 \%, w / w)$-containing solid media. The highest PG productivity reached was 70,402 mg per $\mathrm{kg}$ of TF [93]. The use of rice bran as a C/N source for $S$. marcescens PG production 
was reported by Arivizhivendhan et al., who showed that the PG produced showed antioxidant and antimicrobial activities against foodborne pathogens [92]. Natural substrates such as sweet potato, sesame, and mahua flower extract at different concentrations have also been used for PG production by $S$. marcescens [171]. The highest PG yield was $4800 \mathrm{mg} / \mathrm{L}$ at the final optimized composition of sweet potato powder/casein-containing medium. The purified PG showed antimicrobial [171] and nematicidal [111] activities.

Janthinobacterium lividum BR01 is a psychrotrophic strain that produces PG and heptyl prodigiosin when grown at cool temperatures. The gene cluster of the PG pathway was cloned from J. lividium BR01 and expressed in Escherichia coli, which showed differences in the responsible gene cluster of Serratia sp. [179]. Domröse et al. integrated the PG biosynthesis gene cluster of $S$. marcescens in Pseudomonas putida KT2440 to construct constitutive PG production strains [188]. The PG productivity obtained was $94 \mathrm{mg} / \mathrm{L}$ using the Terrific Broth medium [189]. The PGs productivity of Streptomyces fusant NRCF69, when peanut seed broth, sunflower oil broth, or dairy processing wastewater broth alone or supplemented with $0.5 \%$ mannitol were used as the C/N source, was $42,030 \mathrm{mg} / \mathrm{L}, 40,110 \mathrm{mg} / \mathrm{L}$, $36,700 \mathrm{mg} / \mathrm{L}$, and 47,000 mg/L, respectively [91].

The correlation between extracellular proteases synthesis and PG synthesis in S. marcescens VI was investigated and showed that chloramphenicol (an inhibitor of protein synthesis) inhibits the synthesis of both extracellular proteases and PG [182-194]. Similar results were also observed when using a mixture of 18 natural amino acids; asparagine and ammonium ions repressed the synthesis of both PG and protease [182-194]. On the contrary, leucine exhibited inducing effects on both the synthesis of exocellular protease and PG by S. marcescens VI [182-194]. The biosynthetic pathway for Serratia sp. producing PG involves separate pathways using different metabolites which then couple in the final condensation step [203]. The 5-methyl-4-pentyl-3,4-dihydro-2H-pyrrole and a transaminase have been shown as the intermediates involved in the PG biosynthesis by Serratia sp. ATCC 39006 [204] and involved in the biosynthesis of 2-methyl-3-n-amyl-pyrrole (MAP) from Serratia sp. FS14 [205], respectively.

Based on the hydrophobic properties of PG, efficient extraction procedures for PG purification from the culture supernatant of P. putida [188], Serratia sp. KH-95 [206], and S. marcescens SMDR [207] have been studied by adsorption to the materials with hydrophobic surfaces of polyurethane [188], internal adsorbent using acidified methanol and phase separation [206], and macroporous polymeric adsorption resin of Diaion HP-20 resins [207]. The transmembrane transport of PG producing S. marcescens ATCC 8100 and the permeability barrier of the cell membrane were studied by using a model membrane platform with a planar lipid bilayer [151]. The results showed that the mass transfer of the intracellular PG was affected by its size and surface electrical properties and therefore could be modulated by physical and chemical methods [151]. The immobilization strategy to increase PG production was investigated by Chen et al. [172]. The PG productivity of S. marcescens C3 enhanced seven-fold to $15,600 \mathrm{mg} / \mathrm{L}$ by using immobilized cells in calcium alginate beads. For increasing the recovery yield of PG, adsorption chromatography was studied to separate and purify PG directly. Wang et al. [208] reported that the use of $0.1 \%$ Tween 80 (a nonionic surfactant) may improve the release of PG from the cell envelope. The recovery of PG from the culture broth increased from $50 \%$ (using the conventional method) to $83 \%$ (with a high loading capacity of the adsorbent X-5 resin) [208]. To investigate the extraction methods which may purify PG with high yield and cost-effectivity, Khanam and Chandra tried six different extraction methods including homogenization, ultrasonication, freezing and thawing, heat treatment, organic solvents, and inorganic acids to evaluate the PG yield. The results showed that the highest amount of extraction was achieved by ultrasonication (98.1\%) and the lowest by freezing and thawing (31.8\%) methods [209].

The use of bioadsorbents for adsorption of PG was compared among Lactobacillus paracasei subsp. paracasei TKU012 cells, cicada casting, and four chitin-containing materials including squid pens, shrimp shells, $\alpha$-chitin, and $\beta$-chitin [62]. The best result was observed in L. paracasei subsp. paracasei TKU012, followed by cicada casting, shrimp shells, squid pens, $\beta$-chitin, and $\alpha$-chitin. The cells of 
lactic acid bacterium (strain TKU012) and cicada casting may have the potential to recover and purify PG from the PG-containing culture broth of S. marcescens TKU011 [62]. To increase S. marcescens TKU011 PG production in the medium containing squid pens, the effects of phosphate and ferrous ion supplementation, autoclave treatment, and aeration were studied [60]. The results showed that the 40-min autoclaved medium enhanced PG productivity 2.5 -fold to $2480 \mathrm{mg} / \mathrm{L}$ [60]. Nguyen et al. further investigated PG production by S. marcescens TKU011 using $1 \% \alpha$-chitin and $0.6 \%$ casein as the $\mathrm{C} / \mathrm{N}$ source and obtained the highest yield of $4620 \mathrm{mg} / \mathrm{L}$. $\alpha$-Chitin and $\mathrm{CaSO}_{4}$ were found to play an important role in enhancing PG production by $S$. marcescens [59].

Generally, peanut seed broth received remarkable PG productivity $(47,000 \mathrm{mg} / \mathrm{L})$ which was approximately 10 -fold greater than those using chitin-containing fishery byproducts fermented by S. marcescens TKU011. Considering the utilization of obtaining culture broth for biological control, chitin and protein-containing byproducts (1-3 USD $/ \mathrm{kg}$ ) as the C/N source provide PG, and chitinolytic and proteolytic enzymes might also be expected to have potential applications.

\section{Bioactivity and Application of PG}

\subsection{Antimicrobial Activity}

The antifungal activity of PG produced from S. marcescens is investigated usually against fungal pathogens. The PG from $S$. marcescens $\mathrm{SR}_{1}$ showed the maximum inhibitory activity against the fungal pathogens Helminthosporium sativum, Fusarium oxysporium, and Rhizoctonia solani, in decreasing order [81]. Picha et al. reported that the chitin-supplemented agar medium used for the growth and production of PG by S. marcescens PP1 showed high inhibition to the tested fungal pathogens including Alternaria alternata, Aspergillus niger, and F. oxysporum. The tested fungal species of A. niger, Mucor sp., and Rhizopus sp. were resistant to the produced pigment with no clear zone of inhibition [82]. PG has been reported to display antagonistic effects on the tested fungal strains by increasing permeability in the fungal membrane. Among the tested fungi on potato dextrose agar (PDA) plates, F. oxysporum was highly inhibited by the PG treatment. PG enables $S$. marcescens D1 (an endofungal bacterium) to invade fungal hyphae and spread over the culture of F. oxysporum to result in mycelial death. [213].

In a $0.2 \%$ colloidal chitin supplemented Luria broth, S. marcescens B2 produced PG and four extracellular chitinolytic enzymes which showed antifungal activities against the phytopathogens R. solani (caused cyclamen damping-off and rice sheath blight), F. oxysporum (caused fusarium wilt), and Botrytis cinerea (caused gray mold) [85-87]. These four chitinolytic enzymes were detected among the extracellular proteins of $S$. marcescens B2. Among the four chitinolytic enzymes produced by $S$. marcescens B2, two enzymes showed an inhibitory effect against the spore germination of B. cinerea. The PG extracted and purified from the bacterial cells of $S$. marcescens B2 also showed inhibition against the spore germination of B. cinerea. A synergistic effect of the $S$. marcescens B2 produced PG and chitinolytic enzymes was also observed against the tested fungal pathogens [85-87]. Gutiérrez-Román et al. [88] also reported that the combination of S. marcescens CFFSUR-B2 produced PG and chitinolytic enzymes showed synergistic inhibitory effect on the germination and germ tube growth of Mycosphaerella fijiensis ascospores. Based on the results of toxic effects similar to that of benzimidazole on ascospore germination, the authors suggested that the combination of PG and chitinolytic enzymes may have potential use in the biocontrol of black Sigatoka disease caused by Mycosphaerella fijiensis [88]. S. marcescens ETR17 produced PG, several hydrolytic enzymes (chitinase, protease, cellulase, and lipase), and plant growth-enhancing compounds (iodoacetic acid and siderophore). This strain was isolated as a biocontrol bacterium which showed a remarkable level of inhibitory activities against several foliar and root pathogens of tea [89]. Due to no hemolysin production, the authors concluded that $S$. marcescens ETR17 can be applied to minimize the use of chemical fungicides for disease control in tea gardens [89]. Woodhams et al. [95] reported that $S$. marcescens PG caused remarkable growth inhibition of chytrid fungi Batrachochytrium dendrobatidis and B. salamandrivorans at minimal inhibitory concentrations of 10 
and $50 \mu \mathrm{M}$, respectively [95]. Streptomyces fusant NRCF69 PGs have also exhibited antimycotic activity against clinical dermatophyte isolates (Trichophyton, Microsporum, and Epidermophyton) [91].

The PG produced by S. marcescens PP1 showed higher inhibitory activity against Gram-positive bacteria (Staphylococcus aureus and Bacillus subtilis) than Gram-negative bacteria (E. coli, Pseudomonas aeruginosa, and Klebsiella pneumoniae) [82]. Arivizhivendhan et al. reported the inhibitory activity of $S$. marcescens produced against $P$. aeruginosa [93]. Similar results of antibacterial activities by S. marcescens 2170 PG have also been reported by Herráez et al. [94]. PG produced by S. marcescens UFPEDA 398 showed inhibitory activity against 20 strains of oxacillin-resistant $S$. aureus. The minimum inhibitory concentrations and minimum bactericidal concentrations ranged from $1-4 \mu \mathrm{g} / \mathrm{mL}$ and $2-16$ $\mu \mathrm{g} / \mathrm{mL}$, respectively [83].

Arivizhivendhan et al. also reported that the PG from S. marcescens showed effective antioxidant and antibacterial activities [92]. The extracts of aloe leaf and cucumber fruit are known to have photoprotective activity. The application of PG as antibacterial and antioxidant additives to the extracts of aloe leaf and cucumber fruit has been evaluated for the potential of developing commercial sunscreens for human skin protection [96]. Nakashima et al. reported that a bacterial strain (MS-02-063) that produces large amounts of PGs showed equivalent antibacterial activity to those of tetracycline against some pathogenic Gram-positive bacteria including S. aureus [99]. Pseudoalteromonas rubra synthesizes PG, cycloprodigiosin, and four PG derivatives that differ in the length of the alkyl chain. The antimicrobial activities of the produced PG, cycloprodigiosin, and 2-methyl-3-hexyl-prodiginine have been examined against E. coli, Staphylococcus aureus, Salmonella typhi, and Candida albicans and it was found that cycloprodigiosin potently inhibited S. aureus at a concentration of $20 \mu \mathrm{g} / \mathrm{mL}$ [100].

The antimicrobial effect of PG against microorganisms including antibiotic-resistant pathogens and phytofungal pathogens may provide a potential platform for their use as microbial disinfectants in the fields of pharmaceutical and agricultural biocontrol, respectively.

\subsection{Antiparasitic Activity}

The isolation of antiparasitic compounds from microbial extracts has been widely investigated. The antiparasitic activities of $S$. marcescens produced PG have been evaluated against Plasmodium falciparum and Trypanosoma brucei gambiense. Combinations of PG with phytosynthesized silver and gold nanoparticles showed a remarkable decrease in the $\mathrm{IC}_{50}$ values on both parasites (2.7- to 3.6-fold) without an increase in cytotoxicity to the mammalian cells [102]. The antagonist effect of $S$. marcescens 2170 produced PG has been tested against parasite Trypanosoma cruzi cells. The results showed that the concentration of PG required to suppress $T$. cruzi growth was significantly lower than that required for benznidazole $(0.25 \mathrm{mg} / \mathrm{L}$ and $4.9 \mathrm{mg} / \mathrm{L}$, respectively) [94]. Isaka et al. reported three compounds (metacycloprodigiosin, bafilomycin $\mathrm{A}_{1}$, and spectinabilin) extracted from Streptomyces spectabilis BCC 4785 possessed potent antimalarial activity against $P$. falciparum $\mathrm{K} 1$. Among them, metacycloprodigiosin exhibited potent inhibitory activity $\left(\mathrm{IC}_{50}\right.$ of $0.0050 \mu \mathrm{g} / \mathrm{mL}$ ) against P. falciparum K1 with much lower cytotoxicity [105]. Marchal et al. observed that the presence of a nitrogen atom in the A-ring of PGs is needed for antimalarial activity [107]. Later, the antimalarial activities of four natural and three synthetic PGs were estimated against $P$. falciparum [108]. From a culture of $\alpha$-proteobacteria, Lazaro et al. purified heptyl prodigiosin which showed antimalarial activity similar to that of quinine against the chloroquine-sensitive strain P. falciparum 3D7 [109].

The lack of useful nematicides and the serious damage caused by plant-parasitic nematodes have led to an urgent requirement to isolate some natural remedy for their control [102]. The antinematicidal activity of S. marcescens produced PG has been studied against juvenile stages of Radopholus similis and Meloidogyne javanica. The results showed better activity of this PG ( $\mathrm{LC}_{50}$ values, 83 and $79 \mu \mathrm{g} / \mathrm{mL}$, respectively) than those of the positive control of copper sulfate ( $\mathrm{LC}_{50}$ values, 380 and $280 \mu \mathrm{g} / \mathrm{mL}$, respectively). The PG also showed antagonist effect on nematode egg-hatching ability [102]. 


\subsection{Insecticidal Activity}

Bioagents produced from microbes offer alternatives to chemical pesticides as they can be more selective and safer than chemical insecticides. The insecticidal potency of $S$. marcescens TKU011 PG was investigated and compared with those of food colorants Tartrazine (Y4) and Allura Red AC (R40) against Drosophila larvae [60,61]. The $\mathrm{LC}_{50}$ of PG $(0.23 \mu \mathrm{g} / \mu \mathrm{L}), \mathrm{Y} 4(0.449 \mu \mathrm{g} / \mu \mathrm{L})$, and $\mathrm{R} 40(30 \mu \mathrm{g} / \mu \mathrm{L})$ using a five-day exposure period showed potential toxicity of the biopigment PG and the food colorant Y4 against Drosophila larvae [60]. The order of survival rates of Drosophila larvae after five-day feeding with $30 \mu \mathrm{L}$ of cell broth, broken cell, cell pellet, or cell-free culture supernatant of $S$. marcescens TKU011 were $0 \%, 6.25 \%, 12.5 \%$, and $37.5 \%$, respectively, indicating a direct relationship with their PG content. The fractions with a high PG concentration also exhibited a high insecticidal activity [61].

Patil et al. reported the mosquito larvicidal potential of the crude PG extracted from S. marcescens NMCC46 culture broth against Aedes aegypti and Anopheles stephensi. The $\mathrm{LC}_{50}$ values of second, third, and fourth instars of $A$. aegypti were 41.65, 139.51, and 103.95 and those of A. stephensi were 51.12, 105.52, and 133.07 [110]. Pure PG may be an important molecule for the control of Aedes aegypti and Anopheles stephensi mosquitoes at their larval and pupal stages [111]. Suryawanshi et al. [111] analyzed the effect of the pure PG isolated from S. marcescens NMCC 75 against larval and pupal stages of Aedes aegypti and Anopheles stephensi mosquitoes. The pure PG showed mosquito larvicidal activities with $\mathrm{LC}_{50}$ values of $14,15.6,18$, and $21 \mu \mathrm{g} / \mathrm{mL}$ against the early second, third, fourth instars, and pupal stages of Aedes aegypti, respectively, and with $\mathrm{LC}_{50}$ values of $19.7,24.7,26.6$, and $32.2 \mu \mathrm{g} / \mathrm{mL}$, respectively, against the early second, third, and fourth instars and pupae of Anopheles stephensi, respectively. The results of variation of enzymes (esterases, acetylcholine esterases, phosphatases, and proteases) and total proteins in the fourth instar larvae of Aedes aegypti indicated the intrinsic difference in biochemical features as a result of PG treatment [111]. Zhou et al. observed PG produced by S. marcescens SCQ1 (an entomopathogenic strain isolated from silkworm) causes acute septicemia in silkworms [112]. Asano et al. investigated the synergistic effects of PG, chitinases, and chitin-binding protein from S. marcescens ATCC274 on the insecticidal activity of $\delta$-endotoxin (Cry 1C of Bacillus thuringiensis) against the common cutworm, Spodoptera litura [113]. The results showed that only PG exhibited a remarkable synergistic inhibitory activity with Cry $1 \mathrm{C}$ which was lethal and growth inhibitory. The supernatants from S. marcescens containing PG and partially purified PG exhibited a similar synergistic activity on the insecticidal activity of Cry1C [113].

\subsection{Anti-Cancer Activity}

Several studies have demonstrated the anti-cancer activity of PG in various types of cancer. Zhou et al. reported the PG produced by S. marcescens SCQ1 (an entomopathogenic strain) showed potent anticancer activity on human lung adenocarcinoma A549 cells and concluded that $S$. marcescens SCQ1 may have potential to be used as an anti-cancer compound [112]. To study the role of mitochondria in PG-induced apoptosis, Llagostera et al. evaluated the apoptotic action of PG in GLC4 small cell lung cancer cell line by Hoechst 33342 staining and found that PG induces apoptosis in both caspase-dependent and caspase-independent pathways [119]. The high cytotoxic sensitivity of the human small cell lung doxorubicin-resistant carcinoma (GLC4/ADR) cell line to PG through apoptosis activation was further studied and concluded that the results support PG as a potential drug for the treatment of lung cancer because of its ability to overcome the multidrug resistance phenotype produced by MRP-1 overexpression [120]. The synergistic effects between PG (produced by Vibrio sp. C1-TDSG02-1) and doxorubicin (a chemotherapy drug) against oral squamous cell carcinoma (OSCC) cells was reported by Lin and Wen [118]. Based on the results of PG-priming, autophagy could sensitize OSCC cells by promoting doxorubicin influx without regulation of doxorubicin transporter. Lin and Wen also concluded that the PG (produced by Vibrio sp. C1-TDSG02-1)-priming might be a promising adjuvant approach for the chemotherapy of OSCC [118]. Chiu et al. reported the attenuation of tumors accumulated in the mice trachea by PG (produced by Vibrio sp. C1-TDSG02-1) treatment 
and concluded the potential of PG as a potential chemotherapeutic agent for lung cancer regimens regardless of doxorubicin resistance [116].

Montaner and Perez-Tomas evaluated the apoptotic action of PG in colon cancer cells (DLD-1 and SW-620 human colon adenocarcinoma cells, NRK, and Swiss-3T3 nonmalignant cells) and found that metastatic SW-620 cells were more sensitive to PG than DLD-1. According to the results in both cancer cell lines, the authors suggested that PG induces apoptosis in colon cancer cells [130]. The effect of PG on proliferation and expression of apoptotic-related genes in HT-29 cells was evaluated by Hassankhani et al., who also suggested that PG-induced apoptosis may ascribe to the inhibition of Bcl-2 and survivin in HT-29 cells and these genes may be promising molecular targets of PG [128]. Dalili et al. [129] evaluated the antiproliferative activities of S. marcescens PTCC 1111 produced PG in HT-29 and T47D cancer cell lines. The results showed that HT-29 cells were more sensitive than T47D cells to PG [129]. PG showed higher apoptotic effect than doxorubicin in HT-29 cells. The authors, therefore, suggested the use of PG as a promising antineoplastic agent that triggers apoptosis in different cancer cell lines [129]. Kavitha et al. indicated strong anti-cancer and apoptotic activity of $S$. marcescens PG against human cervical carcinoma cancer, according to the results of dose-dependent inhibition of human cervical carcinoma cell (Hela-229 cell line) proliferation [137]. Díaz-Ruiz et al. found that treatment of human gastric carcinoma cells (HGT-1 cell line) with PG showed a constant decrease in viability due to apoptosis and suggested that PG induces apoptosis in HGT-1 cells [133].

Soto-Cerrato et al. observed potently cytotoxic activity of PG in both estrogen receptor-positive (MCF-7) and negative (MDA-MB-231) breast cancer cell lines and suggested PG as an interesting and potent new pro-apoptotic agent for the treatment of breast cancer despite the presence of multidrug resistance transporter molecules [122,123]. Lu et al. reported that PG could downregulate RAD51 (an attractive target for anticancer drugs) in multiple human breast carcinoma cell lines irrespective of p53 status [126].

To evaluate the immunosuppressive and apoptotic mechanisms of PG, Monge et al. examined the variation of protein expression on exposure to apoptotic concentrations of PG in mitoxantrone (MCF-7-MR) resistant MCF-7 cancer cell line and found that the identified proteins were involved in various cellular functions, including cell defense, DNA repair, and cellular organization [121]. Sam and Pourpak reported that as molecular targets of PG, P53 and survivin contribute to caspase-3-dependent apoptosis in acute lymphoblastic leukemia cells where PG represents an attractive p53- and survivin-modulating agent [134]. Campàs et al. demonstrated that PG induces apoptosis of B-cell chronic lymphocytic leukemia (B-CLL) cells through caspase activation [114]. Liu et al. evaluated the undecylprodigiosin (UPG) extracted from the fermentation broth of Saccharopolyspora sp. (a sponge Mycale plumose-derived actinomycete) and found a significant cytotoxic activity of UPG against five cancer cell lines, especially on murine leukemia P388 [115]. Liu et al. further indicated that UP inhibits proliferation of P388 by inducing G2/M phase arrest and apoptosis, which was related to the activation of P38, JNK rather than ERK1/2 signaling [214]. Based on the observation that PG significantly increased the rate of growth inhibition and decreased metabolic activity of HepG2 cells in a dose- and time-dependent manner, Yenkejeh et al. suggested PG as an attractive compound that may provide a novel approach to the hepatocellular carcinoma-targeted therapy [135].

Based on the results of dose-dependent inhibition of human cervix carcinoma cell (Hela-229 cell line) proliferation by $S$. marcescens, Kavitha et al. suggested strong anticancer and apoptosis activity of PG against human cervical carcinoma cancer [137]. Montaner et al. [142] studied the effects of S. marcescens 2170 culture supernatant on the viability of different hematopoietic cancer cell lines (Jurkat, NSO, HL-60, and Ramos) and nonmalignant cells (NIH-3T3 and MDCK) and found that the cytotoxic effect was due to apoptosis [142]. The results of using mutants of $S$. marcescens (strains OF, WF, and 933) that do not synthesize PG suggested the involvement of PG in this apoptosis [142,143]. Li et al. [143] investigated the anticancer activities and mechanism of activity of $S$. marcescens HDZK-BYSB107 PG by using human choriocarcinoma (JEG3) and prostate cancer cell lines (PC3) in vitro and JEG3 and PC3 tumor-bearing nude mice in vivo [143]. The bacterial PG was observed to induce apoptosis in JEG3 
cells, and PG significantly inhibited the growth of JEG3 and PC3 cells, in a dose and time-dependent manner [143]. Nguyen et al. [59] found that the PG purified from fermentation of chitin-containing medium by S. marcescens TKU011 showed potent anticancer activities against A549, Hep G2, MCF-7, and WiDr with $\mathrm{IC}_{50}$ values of $0.06,0.04,0.04$, and $0.2 \mu \mathrm{g} / \mathrm{mL}$, respectively. For comparison, mitomycin $\mathrm{C}$, a commercial anti-cancer compound was also tested, and it showed weaker activity with $\mathrm{IC}_{50}$ values of $0.11,0.1,0.14$, and $0.15 \mu \mathrm{g} / \mathrm{mL}$, respectively [59]. Muthukumar et al. [145] studied the antioxidant, anti-inflammatory, and cytotoxic properties of PG produced by S. marcescens VITAPI and observed potent radical scavenging effect of the extracted PG at $86 \%$, which was significant in comparison to ascorbic acid as a standard [145]. The in vitro anti-inflammatory effect of PG in controlled experimental conditions revealed its protection at $88 \%$ and inhibition in a concentration-dependent manner. The cytotoxic bioassay of PG showed the $\mathrm{IC}_{50}$ value as $50 \mu \mathrm{g} / \mathrm{mL}$ at $63 \%$ cytotoxicity [145]. El-Bondkly et al. [91] reported the cytotoxic activities of PG pigments produced by Streptomyces fusant NRCF69 against three human cancer cell lines, including colon cancer cell line (HCT-116), liver cancer cell line (HEPG-2), and breast cancer cell line (MCF-7) [91]. The synthesis and evaluation of a series of ten PGs that bear ester and amide substitution about the C-ring of the PG skeleton were reported by Lund et al. [136]. The PG bearing C-ring esters and amides obtained by chemical synthesis displayed anticancer activity, particularly when featuring a hexyl chain [136].

\subsection{Algicidal Activity}

Red tides (harmful algal blooms) are caused by some toxic phytoplankton, and lead to massive economic losses and cause marine environmental disturbances. The PG producing strain Hahella chejuensis KCTC 2396 (a marine bacterium) was evaluated by Kim et al. as an effective and environment-friendly strategy to control red tide outbreaks [148]. The lytic activity of this promising molecule against Cochlodinium polykrikoides cells at very low concentrations (1 ppb) was serendipitously detected, making $H$. chejuensis a strong candidate among the biological agents to control red tides [148]. Nakashima et al. [149] reported that the pigment, PG-L-1 produced by a marine bacterium strain MS-02-063 ( $\gamma$-proteobacterium) exhibited potent algicidal activity against various red tide phytoplanktons in a concentration-dependent manner [99,149]. The authors suggested that PG-L-1 produced by strain MS-02-063 is controlled by the homoserine lactone quorum sensing. This bacterium and other algicidal bacteria may be effective in regulating the blooms of harmful flagellate algae through the quorum sensing system [149].

\subsection{Dyes}

The environmental pollution concerns raised because of the use of chemically synthetic pigment have led to increasing interest in the natural ones. Microbial pigments have lately attracted increasing attention in textile dyeing because of their sustainability and cleaner production $[75-78,151,152,169,210]$. Recently, PG has become a research hotspot for its bright colors and antibacterial function. To promote the application of PG in textile dyeing, a novel idea of preparing dye liquid based on fermentation broth was put forward via increasing the proportion of extracellular pigments [151]. With the improvement in transmembrane transfer efficiency of $S$. marcescens ATCC8100, PG was produced as the proportion of extracellular pigments, and the complicated biological separation process could be avoided and the application of microbial pigments in textile dyeing can be promoted [151].

In the ethanol solution, PG has good stability under natural indoor light but gets rapidly decomposed under intense sunlight [210]. PG is an eco-friendly colorant to dye fabrics, including synthetic and natural fibers. Synthetic fabrics (such as polyamide and acrylic) dyed with PG have high colorfastness to washing and exhibit antimicrobial activities against E. coli and Staphylococcus aureus. Liu et al. [210] reported the promising prospects of S. marcescens jx1-1, with high PG yield and purity, in food, cosmetic, and textile industries.

A strain of Vibrio sp. KSJ45 produced large quantities of bright red PGs with an elementary composition of $\mathrm{C}_{20} \mathrm{H}_{25} \mathrm{~N}_{3} \mathrm{O}$ that could be used to dye many fibers including wool, nylon, acrylics, 
and silk. Fabrics dyed with the PGs produced from Vibrio sp. KSJ45 demonstrated antibacterial activity [101]. Vaidyanathan et al. [211] have studied the application of a novel red biochrome (514 Da in size) produced by solid-state cultivation of Serratia sakuensis subsp. nov. strain KRED in the dyeing of silk, wool, and cotton fabrics. The results showed that silk, wool, and cotton fabrics dyed with this new natural red compound have high color strength and dye uptake values along with good colorfastness as well as antibacterial activity [211]. Mehta and Shah [169] studied the application of PG in the candle industry. The mixture of PG with translucent wax was homogenized and poured into the mold and the candles were left to cool down. After de-molding, the translucent candle showed a more intense coloration, which was similar to the colored candles available in the market, the authors proposed that the synthetic coloring agents can be replaced by natural colorants extracted from microorganisms. The results of the present study on the isolation and application of PG extracted from S. marcescens in the coloration of translucent candles revealed that the pigment PG can be considered as a possible alternate source of colorant in various industries. Table 2 summarizes the bioactivities and applications of PGs reported.

Table 2. Bioactivities and applications of PGs.

\begin{tabular}{|c|c|c|}
\hline Strain & Bioactivity/Application & Reference \\
\hline \multicolumn{3}{|l|}{ (Antimicrobial activity) } \\
\hline S. marcescens UFPEDA398 & antibacterial & [83] \\
\hline S. marcescens IBRL USM 84 & antibacterial & {$[84]$} \\
\hline S. marcescens & antibacterial & [94] \\
\hline S. marcescens & antibacterial & {$[92,93]$} \\
\hline S. marcescens & antibacterial & [97] \\
\hline S. marcescens & anti-chytrid fungi & [95] \\
\hline S. marcescens PP1 & anti-fungal pathogens, antibacterial & [82] \\
\hline S. marcescens CFFSUR-B2 & anti-fungal pathogens & [88] \\
\hline S. marcescens ETR17 & anti-fungal pathogens & [89] \\
\hline S. marcescens & antibacterial & [96] \\
\hline S. marcescens $\mathrm{SR}_{1}$ & anti-fungal pathogens & [81] \\
\hline S. marcescens B2 & anti-fungal pathogens & {$[85,86]$} \\
\hline Streptomyces fusant NRCF69 & antidermatophytic & [91] \\
\hline Strain MS-02-063 & antibacterial & [99] \\
\hline Pseudoalteromonas rubra & antibacterial & [100] \\
\hline Vibrio sp. KSJ45 & antibacterial & [101] \\
\hline \multicolumn{3}{|l|}{ (Anti-parasitic activity) } \\
\hline S. marcescens 2170 & anti-parasitic euglenoids & [94] \\
\hline S. marcescens & anti-parasitic euglenoids & [102] \\
\hline S. marcescens & anti-nematode & [103] \\
\hline S. marcescens & anti-malaria & [104] \\
\hline Streptomyces spectabilis BCC 4785 & anti-malaria & [105] \\
\hline Streptomyces sp. & anti-malaria & [106] \\
\hline Prodigiosene & anti-malaria & [107] \\
\hline Prodiginine & anti-malaria & [108] \\
\hline Heptyl prodigiosin & anti-malaria & [109] \\
\hline \multicolumn{3}{|l|}{ (Insecticidal activity) } \\
\hline S. marcescens TKU011 & fruit fly larvicide & {$[60,61]$} \\
\hline S. marcescens NMCC46 & mosquito larvicide & [110] \\
\hline S. marcescens NMCC75 & mosquito larvicide & [111] \\
\hline S. marcescens SCQ1 & acute septicemia of silkworm & [112] \\
\hline S. marcescens ATCC274 & anti-cutworm & [113] \\
\hline
\end{tabular}


Table 2. Cont.

\begin{tabular}{|c|c|c|}
\hline Strain & Bioactivity/Application & Reference \\
\hline \multicolumn{3}{|l|}{ (Anti-cancer activity) } \\
\hline S. marcescens TKU011 & anti-cancer & [59] \\
\hline S. marcescens TNU01 & anti-cancer & [87] \\
\hline S. marcescens & anti-cancer & [138] \\
\hline S. marcescens & anti-cancer & [147] \\
\hline S. marcescens SCQ1 & anti-lung cancer & [112] \\
\hline Vibrio sp. C1-TDSG02-1 & anti-lung cancer & [116] \\
\hline S. marcescens & anti-lung cancer & {$[119,120]$} \\
\hline S. marcescens & anti-oral cancer & [117] \\
\hline Vibrio sp. C1-TDSG02-1 & anti-oral cancer & [118] \\
\hline S. marcescens & anti-breast cancer & [97] \\
\hline S. marcescens & anti-breast cancer & [121] \\
\hline S. marcescens & anti-breast cancer & [124] \\
\hline S. marcescens & anti-breast cancer & [125] \\
\hline S. marcescens & anti-breast cancer & [126] \\
\hline S. marcescens & anti-breast cancer & [127] \\
\hline S. marcescens & anti-breast cancer & {$[122,123]$} \\
\hline S. marcescens & anti-colorectal cancer & [128] \\
\hline S. marcescens & anti-colorectal cancer & [129] \\
\hline S. marcescens & anti-colorectal cancer & [130] \\
\hline S. marcescens & anti-colorectal cancer & [131] \\
\hline S. marcescens & anti-colorectal cancer & [132] \\
\hline S. marcescens & anti-gastric cancer & [133] \\
\hline S. marcescens & anti-leukemia & [114] \\
\hline S. marcescens & anti-leukemia & [134] \\
\hline Saccharopolyspora sp. & anti-leukemia & [214] \\
\hline S. marcescens & anti-hepatocellular cancer & [135] \\
\hline Prodigiosene & anti-cancer & [136] \\
\hline Prodigiosin & anti-cancer & [141] \\
\hline S. marcescens & anti-cervix carcinoma & [137] \\
\hline S. marcescens MTCC97 & anti-cervix carcinoma & [140] \\
\hline S. marcescens 2170 & anti-hematopoietic cancer & [142] \\
\hline S. marcescens HDZK-BYSB107 & anti-choriocarcinoma & [143] \\
\hline S. marcescens HDZK-BYSB107 & anti-prostate cancer & [143] \\
\hline Streptomyces fusant NRCF69 & anti-colon cancer & [91] \\
\hline S. fusant NRCF69 & anti-liver cancer & [91] \\
\hline S. fusant NRCF69 & anti-breast cancer & [91] \\
\hline \multicolumn{3}{|l|}{ (Anti-oxidation/Anti-inflammatory activity) } \\
\hline S. marcescens VITAPI & anti-oxidation & [145] \\
\hline S. marcescens VITAPI & anti-inflammatory & [145] \\
\hline S. marcescens & immunosuppressive & [147] \\
\hline \multicolumn{3}{|l|}{ (Algicidal activity) } \\
\hline Hahella chejuensis KCTC 239 & algicide & [148] \\
\hline strain MS-02-063 ( $\gamma$-proteobacterium) & algicide & {$[149]$} \\
\hline \multicolumn{3}{|l|}{ (Dyes) } \\
\hline S. marcescens ATCC 8100 & textile & [151] \\
\hline Serratia sp. KH-1 & textile & [152] \\
\hline S. marcescens & candle & [163] \\
\hline S. marcescens & sunscreen & [96] \\
\hline Serratia rubidaea & textile & {$[154,177]$} \\
\hline Vibrio sp. KSJ45 & textile & [101] \\
\hline
\end{tabular}

\section{Conclusions and Perspectives}

Pigments of various kinds and forms have been used as additives or supplements in the food industry, cosmetics, pharmaceuticals, biocontrol, and other applications. Recently, in response to 
the problems of the synthetic pigments that cause toxicity and carcinogenicity in the human body, the inclination to use natural pigments as adding natural materials for human health and safety has gradually expanded. This review contains the most recent information on the production of PGs from various bacteria especially $S$. marcescens. For PG production, the commercial media of peptone and yeast extract supplemented with vegetable oil have been used for enhancing PG productivity. Considering the bioactivities of PG, anti-cancer applications have been most widely studied. Compared to the use of expensive media supplemented with vegetable oils, chitin and protein-containing fishery byproducts have more potential for PG production.

The discovery of inexpensive PG not only solves environmental problems but also promotes the economic value of marine wastes. Furthermore, the chitinolytic and proteolytic enzymes together with PG produced by $S$. marcescens TKU011 using fishery byproducts can enhance antimicrobial activities and may be a potential source of biological control agents.

Author Contributions: Conceptualization, S.-L.W., V.B.N., C.T.D., T.N.T., M.T.N., and A.D.N.; validation, S.-L.W.; resources, S.-L.W.; data curation, S.-L.W. and V.B.N.; writing-original draft preparation, S.-L.W.; writing-review and editing, S.-L.W.; visualization, S.-L.W.; supervision, S.-L.W.; project administration, S.-L.W. All authors have read and agreed to the published version of the manuscript.

Funding: This study was supported in part by a grant from the Ministry of Science and Technology, Taiwan (MOST 106-2320-B-032-001-MY3).

Conflicts of Interest: The authors declare no conflict of interest.

\section{References}

1. Tran, N.V.N.; Yu, J.; Nguyen, T.P.; Wang, S.L. Coagulation of chitin production wastewater from shrimp scraps with by-product chitosan and chemical coagulants. Polymers 2020, 12, 607. [CrossRef] [PubMed]

2. Ha, N.M.C.; Wang, S.L.; Nguyen, A.D. Preparation of NPK nanofertilizer based on chitosan nanoparticles and its effect on biophysical characteristics and growth of coffee in green house. Res. Chem. Intermed. 2019, 45, 51-63. [CrossRef]

3. Shaala, L.A.; Asfour, H.Z.; Youssef, D.T.A.; Zółtowska-Aksamitowska, S.; Wysokowski, M.; Tsurkan, M.; Galli, R.; Meissner, H.; Petrenko, I.; Tabachnick, K.; et al. New source of 3D chitin scaffolds: The Red Sea demosponge Pseudoceratina arabica (Pseudoceratinidae, Verongiida). Mar. Drugs 2019, 17, 92. [CrossRef] [PubMed]

4. Casadidio, C.; Peregrina, D.V.; Gigliobianco, M.R.; Deng, S.; Censi, R.; Di Martino, P. Chitin and chitosans: Characteristics, eco-friendly processes, and applications in cosmetic science. Mar. Drugs 2019, 17, 369. [CrossRef] [PubMed]

5. Doan, C.T.; Tran, T.N.; Nguyen, V.B.; Vo, T.P.K.; Nguyen, A.D.; Wang, S.L. Chitin extraction from shrimp waste by liquid fermentation using an alkaline protease-producing strain, Brevibacillus parabrevis. Int. J. Biol. Macromol. 2019, 131, 706-715. [CrossRef] [PubMed]

6. Doan, C.T.; Tran, T.N.; Nguyen, V.B.; Nguyen, A.D.; Wang, S.L. Production of a thermostable chitosanase from shrimp heads via Peanibacillus mucilaginosus TKU032 conversion and its application in the preparation of bioactive chitosan oligosaccharides. Mar. Drugs 2019, 17, 217. [CrossRef] [PubMed]

7. El-Naggar, M.; Abou-Elmagd, W.S.I.; Suloma, A.; El-Shabaka, H.A.; Khalil, M.T.; El-Rahman, F.A.A. Optimization and physicochemical characterization of chitosan and chitosan nanoparticles extracted from the crayfish Procambarus clarkii wastes. J. Shellfish Res. 2019, 38, 385. [CrossRef]

8. Kaczmarek, M.B.; Struszczyk-Swita, K.; Li, X.; Szczęsna-Antczak, M.; Daroch, M. Enzymatic modifications of chitin, chitosan, and chitooligosaccharides. Front. Bioeng. Biotechnol. 2019, 7, 243. [CrossRef]

9. Wang, C.H.; Doan, C.T.; Nguyen, V.B.; Nguyen, A.D.; Wang, S.L. Reclamation of fishery processing waste: A mini-review. Molecules 2019, 24, 2234. [CrossRef]

10. Santos-Moriano, P.; Fernandez-Arrojo, L.; Mengibar, M.; Belmonte-Reche, E.; Peñalver, P.; Acosta, F.; Ballesteros, A.; Morales, J.; Kidibule, P.; Fernandez-Lobato, M.; et al. Enzymatic production of fully deacetylated chitooligosaccharides and their neuroprotective and anti-inflammatory properties. Biocatal. Biotransform. 2018, 1, 36. [CrossRef] 
11. Pighinelli, W.L.; Broquá, J.; Zanin, B.G.; Zanin, B.G.; Flach, A.M.; Mallmann, C.; Taborda, F.G.D.; Machado, L.E.L.; Alves, S.M.L.; Silva, M.M.; et al. Methods of chitin production a short review. Am. J. Biomed. Sci. Res. 2019, 3, AJBSR.MS.ID.000682. [CrossRef]

12. Oh, Y.S.; Shieh, I.L.; Tzeng, Y.M.; Wang, S.L. Protease produced by Pseudomonas aeruginosa K-187 and its application in the deproteinization of shrimp and crab shell wastes. Enzyme Microb. Technol. 2000, 27, 3-10. [CrossRef]

13. Yang, J.K.; Shih, I.L.; Tzeng, Y.M.; Wang, S.L. Production and purification of protease from a Bacillus subtilis that can deproteinize crustacean wastes. Enzyme Microb. Technol. 2010, 26, 406-413. [CrossRef]

14. Wang, S.L.; Chio, S.H. Deproteinization of shrimp and crab shell with the protease of Pseudomonas aeruginosa K-187. Enzyme Microb. Technol. 1998, 22, 629-633. [CrossRef]

15. Wang, S.L.; Liang, T.W.; Yen, Y.H. Bioconversion of chitin-containing wastes for the production of enzymes and bioactive materials (review paper). Carbohydr. Polym. 2011, 84, 732-742. [CrossRef]

16. Wang, S.L. Microbial reclamation of squid pen. Biocatal. Agric. Biotechnol. 2012, 1, 177-180. [CrossRef]

17. Abu-Tahon, M.; Isaac, G.S. Anticancer and antifungal efficiencies of purified chitinase produced from Trichoderma viride under submerged fermentation. J. Gen. Appl. Microbiol. 2020, 66, 32-40. [CrossRef]

18. Zhang, Y.; Zhou, Z.; Liu, Y.; Cao, Y.; He, S.; Huo, F.; Qin, C.; Yao, B.; Ringø, E. High-yield production of a chitinase from Aeromonas veronii B565 as a potential feed supplement for warm-water aquaculture. Appl. Microbiol. Biotechnol. 2014, 98, 1651-1662. [CrossRef]

19. Doan, C.T.; Tran, T.N.; Nguyen, M.T.; Nguyen, V.B.; Nguyen, A.D.; Wang, S.L. Anti- $\alpha$-glucosidase activity by a protease from Bacillus licheniformis. Molecules 2019, 24, 691. [CrossRef]

20. Doan, C.T.; Tran, T.N.; Wen, I.H.; Nguyen, V.B.; Nguyen, A.D.; Wang, S.L. Conversion of shrimp head waste for production of a thermotolerant, detergent-stable, alkaline protease by Paenibacillus sp. Catalysts 2019, 9, 798. [CrossRef]

21. Huynh, N.T.; Suyotha, W.; Yano, S.; Konno, H.; Cheirsilp, B.; Wakayama, M. Low-cost production of chitosanolytic enzymes from Lentzea sp. strain OUR-I1 for the production of antimicrobial substances against food-borne pathogens. Int. Food Res. J. 2019, 26, 1293-1304.

22. Tran, T.N.; Doan, C.T.; Nguyen, M.T.; Nguyen, V.B.; Vo, T.P.K.; Nguyen, A.D.; Wang, S.L. An exochitinase with $\mathrm{N}$-acetyl- $\beta$-glucosaminidase activity from shrimp heads conversion by Streptomyces speibonae and its application in hydrolyzing $\beta$-chitin powder to produce $N$-acetyl-D-glucosamine. Polymers 2019, 11, 1600. [CrossRef] [PubMed]

23. Tran, T.N.; Doan, C.T.; Nguyen, V.B.; Nguyen, A.D.; Wang, S.L. The isolation of chitinase from Streptomyces thermocarboxydus and its application in the preparation of chitin oligomers. Res. Chem. Intermed. 2019, 45, 727-742. [CrossRef]

24. Doan, C.T.; Tran, T.N.; Nguyen, V.B.; Nguyen, A.D.; Wang, S.L. Reclamation of marine chitinous materials for chitosanase production via microbial conversion by Paenibacillus macerans. Mar. Drugs 2018, 16, 429. [CrossRef] [PubMed]

25. Doan, C.T.; Tran, T.N.; Nguyen, V.B.; Nguyen, A.D.; Wang, S.L. Conversion of squid pens to chitosanases and proteases via Paenibacillus sp. TKU042. Mar. Drugs 2018, 16, 83. [CrossRef] [PubMed]

26. Wang, S.L.; Liang, T.W. Microbial reclamation of squid pens and shrimp shells. Res. Chem. Intermed. 2017, 43, 3445-3462. [CrossRef]

27. Liang, T.W.; Chen, W.T.; Lin, Z.H.; Kuo, Y.H.; Nguyen, A.D.; Pan, P.S.; Wang, S.L. An amphiprotic novel chitosanase from Bacillus mycoides and its application in the production of chitooligomers with their antioxidant and anti-inflammatory evaluation. Int. J. Mol. Sci. 2016, 17, 1302. [CrossRef]

28. Liang, T.W.; Lo, B.C.; Wang, S.L. Chitinolytic bacteria-assisted conversion of squid pen and its effect on dyes and pigments adsorption. Mar. Drugs 2015, 13, 4576-4593. [CrossRef]

29. Nguyen, A.D.; Huang, C.C.; Liang, T.W.; Nguyen, V.B.; Pan, P.S.; Wang, S.L. Production and purification of a fungal chitosanase and chitooligomers from Penicillium janthinellum D4 and discovery of the enzyme activators. Carbohydr. Polym. 2014, 108, 331-337. [CrossRef]

30. Wang, C.L.; Su, J.W.; Liang, T.W.; Nguyen, A.D.; Wang, S.L. Production, purification and characterization of a chitosanase from Bacillus cereus. Res. Chem. Intermed. 2014, 40, 2237-2248. [CrossRef]

31. Zhang, H.; Zhang, W. Induction and optimization of chitosanase production by Aspergillus fumigatus YT-1 using response surface methodology. Chem. Biochem. Eng. Q. 2013, 27, 335-345. 
32. Brzezinska, M.S.; Walczak, M.; Lalke-Porczyk, E.; Donderski, W. Utilization of shrimp-shell waste as a substrate for the activity of chitinases produced by microorganisms. Pol. J. Environm. Stud. 2010, 19, 177-182.

33. Wang, S.L.; Hsu, W.H.; Liang, T.W. Conversion of squid pen by Pseudomonas aeruginosa K187 fermentation for the production of $N$-acetyl chitooligosaccharides and biofertilizers. Carbohydr. Res. 2010, 345, 880-885. [CrossRef] [PubMed]

34. Wang, S.L.; Chang, T.J.; Liang, T.W. Conversion and degradation of shellfish wastes by Serratia sp. TKU016 fermentation for the production of enzymes and bioactive materials. Biodegradation 2010, 21, 321-333. [CrossRef] [PubMed]

35. Chang, W.T.; Chen, M.L.; Wang, S.L. An antifungal chitinase produced by Bacillus subtilis using chitin waste as a carbon source. World J. Microbiol. Biotechnol. 2010, 26, 945-950. [CrossRef]

36. Liang, T.W.; Kuo, Y.H.; Wu, P.C.; Wang, C.L.; Dzung, N.A.; Wang, S.L. Purification and characterization of a chitosanase and a protease by conversion of shrimp shell wastes fermented by Serratia marcescens subsp. sakuensis TKU019. J. Chin. Chem. Soc. 2010, 57, 857-863. [CrossRef]

37. Wang, S.L.; Peng, J.H.; Liang, T.W.; Liu, K.C. Purification and characterization of a chitosanase from Serratia marcescens TKU011. Carbohydr. Res. 2008, 343, 1316-1323. [CrossRef]

38. Wang, S.L.; Yeh, P.Y. Purification and characterization of a chitosanases from a nattokinase producing strain Bacillus subtilis TKU007. Process Biochem. 2008, 43, 132-138. [CrossRef]

39. Ruiz-Sànchez, A.; Cruz-amarillo, R.; Salcedo-Hernandez, R.; Barboza-Corona, J.E. Chitinases from Serratia marcescens Nima. Biotechnol. Lett. 2005, 27, 649-653. [CrossRef]

40. Wang, S.L.; Huang, T.Y.; Wang, C.Y.; Liang, T.W.; Yen, Y.H.; Sakata, Y. Bioconversion of squid pen by Lactobacillus paracasei subsp. paracasei TKU010 for the production of proteases and lettuce growth enhancing biofertilizers. Bioresour. Technol. 2008, 99, 5436-5443. [CrossRef]

41. Liang, T.W.; Yen, Y.H.; Lin, J.J.; Wang, S.L. Purification and characterization of a protease extracellularly produced by Monascus purpureus CCRC31499 in a shrimp and crab shell powder medium. Enzyme Microb. Technol. 2006, 38, 74-80. [CrossRef]

42. Wang, S.L.; Lin, T.Y.; Yen, Y.H.; Liao, H.F.; Chen, Y.J. Bioconversion of shellfish chitin wastes for the production of Bacillus subtilis W-118 chitinase. Carbohydr. Res. 2006, 341, 2507-2515. [CrossRef] [PubMed]

43. Chang, W.T.; Chen, J.S.; Wang, S.L. An antifungal chitinase produced by Bacillus cereus with shrimp and crab shell powder as a carbon source. Curr. Microbiol. 2003, 47, 102-108. [CrossRef] [PubMed]

44. Wang, S.L.; Hsiao, W.J.; Chang, W.T. Purification and characterization of an antimicrobial chitinase extracellularly produced by Monascus purpureus CCRC31499 in a shrimp and crab shell powder medium. J. Agric. Food Chem. 2002, 50, 2249-2255. [CrossRef] [PubMed]

45. Wang, S.L.; Yen, Y.H.; Tsiao, W.J.; Chang, W.T.; Wang, C.L. Production of antimicrobial compounds by Monascus purpureus CCRC31499 using shrimp and crab shell powder as a carbon source. Enzyme Microb. Technol. 2002, 31, 337-344. [CrossRef]

46. Wang, S.L.; Shih, I.L.; Liang, T.W.; Wang, C.H. Purification and characterization of two antifungal chitinases extracellularly produced by Bacillus amyloliquefaciens V656 in a shrimp and crab shell powder medium. J. Agric. Food Chem. 2002, 50, 2241-2248. [CrossRef]

47. Wang, S.L.; Shih, I.L.; Wang, C.H.; Chang, W.T.; Tu, Y.G.; Ro, J.J.; Wang, C.L. Production of antifungal compounds from chitin by Bacillus subtilis. Enzyme Microb. Technol. 2002, 31, 321-328.

48. Wang, S.L.; Yieh, T.C.; Shieh, I.L. Purification and characterization of a new antifungal compound produced by Pseudomonas aeruginosa K-187 in a shrimp and crab shell powder medium. Enzyme Microb. Technol. 1999, 25, 439-446. [CrossRef]

49. Wang, S.L.; Yieh, T.C.; Shih, I.L. Production of antifungal compounds by Pseudomonas aeruginosa K-187 using shrimp and crab shell powder as a carbon source. Enzyme Microb. Technol. 1999, 25, 142-148. [CrossRef]

50. Wang, S.L.; Chang, W.T. Purification and characterization of two bifunctional chitinases/lysozymes extracellularly produced by Pseudomonas aeruginosa K-187 in a shrimp and crab shell powder medium. Appl. Environ. Microbiol. 1997, 63, 380-386. [CrossRef]

51. Liang, T.W.; Jen, S.N.; Nguyen, A.D.; Wang, S.L. Application of chitinous materials in production and purification of a poly(L-lactic acid) depolymerase from Pseudomonas tamsuii TKU015. Polymers 2016, 8, 98. [CrossRef] [PubMed]

52. Wang, S.L.; Wu, Y.Y.; Liang, T.W. Purification and biochemical characterization of a nattokinase by conversion of shrimp shell with Bacillus subtilis TKU007. New Biotechnol. 2011, 28, 196-202. [CrossRef] [PubMed] 
53. Liang, T.W.; Lee, Y.C.; Wang, S.L. Tyrosinase inhbitory activity of supernatant and semi-purified extracts from squid pen fermeted with Burkholderia cepacia TKU025. Res. Chem. Intermed. 2015, 41, 6105-6116. [CrossRef]

54. Hsu, C.H.; Nguyen, A.D.; Chen, Y.W.; Wang, S.L. Tyrosinase inhibitors and insecticidal materials produced by Burkholderia cepacia using squid pen as the sole carbon and nitrogen source. Res. Chem. Intermed. 2014, 40, 2249-2258. [CrossRef]

55. Liang, T.W.; Tseng, S.C.; Wang, S.L. Production and characterization of antioxidant properties of exopolysaccharides from Paenibacillus mucilaginosus TKU032. Mar. Drugs 2016, 14, 40. [CrossRef]

56. Liang, T.W.; Wang, S.L. Recent advances in exopolysaccharides from Paenibacillus spp.: Production, isolation, structure, and bioactivities-review. Mar. Drugs 2015, 13, 1847-1863. [CrossRef]

57. Wang, S.L.; Li, H.T.; Zhang, L.J.; Lin, Z.H.; Kuo, Y.H. Conversion of squid pen to homogentisic acid via Paenibacillus sp. TKU036 and the antioxidant and anti-inflammatory activities of homogentisic acid. Mar. Drugs 2016, 14, 183. [CrossRef]

58. Nguyen, V.B.; Nguyen, T.H.; Doan, C.T.; Tran, T.N.; Nguyen, A.D.; Kuo, Y.H.; Wang, S.L. Production and bioactivity-guided isolation of antioxidants with $\alpha$-glucosidase inhibitory and anti-NO properties from marine chitinous materials. Molecules 2018, 23, 1124. [CrossRef]

59. Nguyen, V.B.; Chen, S.P.; Nguyen, T.H.; Nguyen, M.T.; Tran, T.T.T.; Doan, C.T.; Tran, T.G.; Nguyen, A.D.; Kuo, Y.H.; Wang, S.L. Novel efficient bioprocessing of marine chitins into active anticancer prodigiosin. Mar. Drugs 2020, 18, 15. [CrossRef]

60. Liang, T.W.; Chen, S.Y.; Chen, C.H.; Yen, Y.H.; Wang, S.L. Enhancement of prodigiosin production by Serratia marcescens TKU011 and its insecticidal activity relative to food colorants. J. Food Sci. 2013, 78, 1743-1751. [CrossRef]

61. Wang, S.L.; Wang, C.Y.; Yen, Y.H.; Liang, T.W.; Chen, S.Y.; Chen, C.H. Enhanced production of insecticidal prodigiosin from Serratia marcescens TKU011 in media containing squid pen. Process Biochem. 2012, 47, 1684-1690. [CrossRef]

62. Wang, S.L.; Chen, S.Y.; Yen, Y.H.; Liang, T.W. Utilization of chitinous materials in pigment adsorption. Food Chem. 2012, 135, 1134-1140. [CrossRef] [PubMed]

63. Nguyen, V.B.; Wang, S.L. Production of potent antidiabetic compounds from shrimp head powder via Paenibacillus conversion. Process Biochem. 2019, 76, 18-24. [CrossRef]

64. Nguyen, V.B.; Wang, S.L. New novel $\alpha$-glucosidase inhibitors produced by microbial conversion. Process Biochem. 2018, 65, 228-232. [CrossRef]

65. Nguyen, V.B.; Wang, S.L. Reclamation of marine chitinous materials for the production of $\alpha$-glucosidase inhibitors via microbial conversion. Mar. Drugs 2017, 15, 350. [CrossRef] [PubMed]

66. Nguyen, V.B.; Nguyen, A.D.; Wang, S.L. Utilization of fishery processing $\alpha$-glucosidase inhibitors production by Paenibacillus sp. Mar. Drugs 2017, 15, 274. [CrossRef]

67. Nguyen, V.B.; Nguyen, A.D.; Kuo, Y.H.; Wang, S.L. Biosynthesis of $\alpha$-glucosidase inhibitors by a newly isolated bacterium, Paenibacillus sp. TKU042 and its effect on reducing plasma glucose in mouse model. Int. J. Mol. Sci. 2017, 18, 700. [CrossRef]

68. Liang, T.W.; Chen, Y.J.; Yen, Y.H.; Wang, S.L. The antitumor activity of the hydrolysates of chitinous materials hydrolyzed by crude enzyme from Bacillus amyloliquefaciens V656. Process Biochem. 2007, 42, 527-534. [CrossRef]

69. Kuo, Y.H.; Liang, T.W.; Liu, K.C.; Hsu, Y.W.; Hsu, H.C.; Wang, S.L. Isolation and identification of a novel antioxidant with antitumour activity from Serratia ureilytica using squid pen as fermentation substrate. Mar. Biotechnol. 2011, 13, 451-461. [CrossRef]

70. Rashid, H.A.; Jung, H.Y.; Kim, J.K. Enhanced reutilization value of shrimp-shell waste via fed-batch biodegradation with higher production of reducing sugar, antioxidant, and DNA protective compounds. Fish. Aquat. Sci. 2018, 21, 33. [CrossRef]

71. Wang, S.L.; Liu, K.C.; Liang, T.W.; Kuo, Y.H.; Wang, C.Y. In vitro antioxidant activity of liquor and semi-purified fractions from fermented squid pen biowaste by Serratia ureilytica TKU013. Food Chem. 2010, 119, 1380-1385. [CrossRef]

72. Wang, S.L.; Li, J.Y.; Liang, T.W.; Hsieh, J.L.; Tseng, W.N. Conversion of shrimp shell by using Serratia sp. TKU017 fermentation for the production of enzymes and antioxidants. J. Microbiol. Biotechnol. 2010, 20, 117-126. [CrossRef] [PubMed] 
73. Liang, T.W.; Chen, C.H.; Wang, S.L. Production of insecticidal materials from Pseudomonas tamsuii. Res. Chem. Intermed. 2015, 41, 7965-7971. [CrossRef]

74. Liang, T.W.; Huang, C.T.; Nguyen, A.D.; Wang, S.L. Squid pen chitin oligomers as pigment adsorbents. Mar. Drugs 2015, 13, 681-696. [CrossRef] [PubMed]

75. Ramesh, C.; Vinithkumar, N.V.; Kirubagaran, R.; Venil, C.K.; Dufossé, L. Multifaceted applications of microbial pigments: Current knowledge, challenges and future directions for public health implications. Microorganisms 2019, 7, 186. [CrossRef] [PubMed]

76. Mumtaz, R.; Bashir, S.; Numan, M.; Shinwari, Z.K.; Ali, M. Pigments from soil bacteria and their therapeutic properties: A mini review. Curr. Microbiol. 2019, 76, 783-790. [CrossRef]

77. Soliev, A.B.; Hosokawa, K.; Enomoto, K. Bioactive pigments from marine bacteria: Applications and physiological roles. Evid.-Based Complement. Altern. Med. 2011, 2011, 670349-670356. [CrossRef]

78. Chang, C.C.; Chen, W.C.; Ho, T.F.; Wu, H.S.; Wei, Y.H. Development of natural anti-tumor drugs by microorganism. J. Biosci. Bioeng. 2011, 111, 501-511. [CrossRef]

79. Akilandeswari, P.; Pradeep, B.V. Exploration of industrially important pigments from soil fungi. Appl. Microbiol. Biotechnol. 2016, 100, 1631-1643. [CrossRef]

80. Numan, M.; Bashir, S.; Mumtaz, R.; Tayyab, S.; Rehman, N.U.; Khan, A.L.; Shinwari, Z.K.; Al-Harrasi, A. Therapeutic applications of bacterial pigments: A review of current status and future opportunities. 3 Biotech 2018, 8, 207. [CrossRef]

81. Parani, K.; Saha, B.K. Optimization of prodigiosin production from a strain of Serratia marcescens $\mathrm{SR}_{1}$ and screening for antifungal activity. J. Biol. Control 2008, 22, 73-79.

82. Picha, P.; Kale, D.; Dave, I.; Pardeshi, S. Comparative studies on prodigiosin production by Serratia marcescens using various crude fatty acid sources-its characterization and applications. Int. J. Curr. Microbiol. Appl. Sci. 2015, 2, 254-267.

83. Lapenda, J.C.; Silva, P.A.; Vicalvi, M.C.; Sena, K.X.F.R.; Nascimento, S.C. Antimicrobial activity of prodigiosin isolated from Serratia marcescens UFPEDA 398. World J. Microbiol. Biotechnol. 2015, 31, 399-406. [CrossRef] [PubMed]

84. Ibrahim, D.; Nazari, T.F.; Kassim, J.; Lim, S.H. Prodigiosin-an antibacterial red pigment produced by Serratia marcescens IBRL USM 84 associated with a marine sponge Xestopongia testudinaria. J. Appl. Pharm. Sci. 2014, 4, 001-006. [CrossRef]

85. Someya, N.; Nakajima, M.; Watanabe, K.; Hibi, T.; Akutsu, K. Potential of Serratia marcescens strain B2 for biological control of rice sheath blight. Biocontrol Sci. Technol. 2005, 15, 105-109. [CrossRef]

86. Someya, N.; Nakajima, M.; Hirayae, K.; Hibi, T.; Akutsu, K. Synergistic antifungal activity of chitinolytic enzymes and prodigiosin produced by biocontrol bacterium, Serratia marcescens strain B2 against gray mold pathogen, Botrytis cinerea. J. Gen. Plant Pathol. 2001, 67, 312-317. [CrossRef]

87. Nguyen, V.B.; Nguyen, D.N.; Wang, S.L. Microbial reclamation of chitin and protein-containing marine by-products for the production of prodigiosin and the evaluation of its bioactivities. Polymers 2020, 12, 1328.

88. Gutiérrez-Román, M.I.; Holguin-Melendez, F.; Dunn, F.M.; Guillén-Navarro, K.; Huerta, G. Antifungal activity of Serratia marcescens CFFSUR-B2 purified chitinolytic enzymes and prodigiosin against Mycosphaerella fijiensis, causal agent of black Sigatoka in banana (Musa spp.). BioControl 2015, 60, 565-572. [CrossRef]

89. Purkayastha, G.D.; Mangar, P.; Saha, A.; Saha, D. Evaluation of the biocontrol efficacy of a Serratia marcescens strain indigenous to tea rhizosphere for the management of root rot disease in tea. PLoS ONE 2018, 13, e0191761. [CrossRef]

90. Gutiérrez-Román, M.I.; Holguín-Meléndez, F.; Bello-Mendoza, R.; GuillénNavarro, K.; Dunn, M.F.; Huerta-Palacios, G. Production of prodigiosin and chitinases by tropical Serratia marcescens strains with potential to control plant pathogens. World J. Microbiol. Biotechnol. 2012, 28, 145-153. [CrossRef]

91. El-Bondkly, A.M.A.; El-Gendy, M.M.A.; Bassyouni, R.H. Overproduction and biological activity of prodigiosin-like pigments from recombinant fusant of endophytic marine Streptomyces species. Antonie van Leeuwenhoek 2012, 102, 719-734. [CrossRef] [PubMed]

92. Arivizhivendhan, K.V.; Mahesh, M.; Boopathy, R.; Swarnalatha, S.; Regina Mary, R.; Sekaran, G. Antioxidant and antimicrobial activity of bioactive prodigiosin produces from Serratia marcescens using agricultural waste as a substrate. J. Food Sci. Technol. 2018, 55, 2661-2670. [CrossRef] [PubMed] 
93. Arivizhivendhan, K.V.; Mahesh, M.; Regina Mary, R.; Sekaran, G. Bioactive prodigiosin isolated from Serratia marcescens using solid state fermenter and its bactericidal activity compared with conventional antibiotics. J. Microb. Biochem. Technol. 2015, 7, 305-312.

94. Herráez, R.; Murm, A.; Merlos, A.; Viñas, M.; Vinuesa, T. Using prodigiosin against some gram-positive and gram-negative bacteria and Trypanosoma cruzi. J. Venom Anim. Toxins Incl. Trop. Dis. 2019, 25, e20190001. [CrossRef]

95. Woodhams, D.C.; LaBumbard, B.C.; Barnhart, K.L.; Becker, M.H.; Bletz, M.C.; Escobar, L.A.; Flechas, S.V.; Forman, M.E.; Iannetta, A.A.; Joyce, M.D.; et al. Prodigiosin, violacein, and volatile organic compounds produced by widespread cutaneous bacteria of amphibians can inhibit two Batrachochytrium fungal pathogens. Microb. Ecol. 2018, 75, 1049-1062. [CrossRef]

96. Suryawanshi, R.K.; Patil, C.D.; Borase, H.P.; Narkhede, C.P.; Stevenson, A.; Hallsworth, J.E.; Patil, S.V. Towards an understanding of bacterial metabolites prodigiosin and violacein and their potential for use in commercial sunscreens. Int. J. Cosmet. Sci. 2015, 37, 98-107. [CrossRef]

97. Sruthy, P.B.; Anjana, J.C.; Rathinamala, J.; Jayashree, S. The role of red pigment prodigiosin from bacteria of earthworm gut as an anticancer agent. J. Microbiol. Biotechnol. Food Sci. 2017, 4, 246-251.

98. Hsieh, H.Y.; Shieh, J.J.; Chen, C.J.; Pan, M.Y.; Yang, S.Y.; Lin, S.C.; Chang, J.S.; Lee, A.Y.; Chang, C.C. Prodigiosin down-regulats SKP2 to induce p27(KIP1) stabilization and antiproliferation in human lung adenocarcinoma cells. Br. J. Pharmacol. 2012, 166, 2095-2108. [CrossRef]

99. Nakashima, T.; Kurachi, M.; Kato, Y.; Yamaguchi, K.; Oda, T. Characterization of bacterium isolated from the sediment at coastal area of Omura Bay in Japan and several biological activities of pigment produced by this isolate. Microbiol. Immunol. 2005, 49, 407-415. [CrossRef]

100. Setiyono, E.; Adhiwibawa, M.A.S.; Indrawati, R.; Prihastyanti, M.N.T.; Shioi, Y.; Brotosudarmo, T.H.P. An Indonesian marine bacterium, Pseudoalteromonas rubra, produces antimicrobial prodiginine pigments. ACS Omega 2020, 5, 4626-4635. [CrossRef] [PubMed]

101. Alihosseini, F.; Ju, K.S.; Lango, J.; Hammock, B.D.; Gang, G. Antibacterial colorants: Characterization of prodiginines and their applicationson textile. Biotechnol. Prog. 2008, 24, 742-747. [CrossRef] [PubMed]

102. Rahul, S.; Chandrashekhar, P.; Hemant, B.; Bipinchandra, S.; Mouray, E.; Grellier, P.; Satish, P. In vitro antiparasitic activity of microbial pigments and their combination with phytosynthesized metal nanoparticles. Parasitol. Int. 2015, 64, 353-356. [CrossRef] [PubMed]

103. Rahul, S.; Chandrashekhar, P.; Hemant, B.; Chandrakant, N.; Laxmikant, S.; Satish, P. Nematicidal activity of microbial pigment from Serratia marcescens. Nat. Prod. Res. 2014, 28, 1399-1404. [CrossRef] [PubMed]

104. Castro, A. Antimalarial activity of prodigiosin. Nature 1967, 213, 903-904. [PubMed]

105. Isaka, M.; Jaturapat, A.; Kramyu, J.; Tanticharoen, M.; Thebtaranonth, Y. Potent in vitro antimalarial activity of metacycloprodigiosin isolated from Streptomyces spectabilis BCC 4785. Antimicrob. Agents Chemother. 2002, $46,1112-1113$.

106. Gerber, N.N. A new prodiginne (prodigiosin-like) pigment from Streptomyces. Antimalarial activity of several prodiginnes. J. Antibiot. (Tokyo) 1975, 28, 194-199. [CrossRef]

107. Marchal, E.; Smithen, D.A.; Uddin, M.I.; Robertson, A.W.; Jakeman, D.L.; Mollard, V.; Goodman, C.D.; MacDougall, K.S.; McFarland, S.A.; McFadden, G.I.; et al. Synthesis and antimalarial activity of prodigiosenes. Org. Biomol. Chem. 2014, 12, 4132-4142.

108. Papireddy, K.; Smilkstein, M.; Kelly, J.X.; Shweta, S.; Salem, S.M.; Alhamadsheh, M.; Haynes, S.W.; Challis, G.L.; Reynolds, K.A. Antimalarial activity of natural and synthetic prodiginines. J. Med. Chem. 2011, 54, 5296-5306. [CrossRef]

109. Lazaro, J.E.; Nitcheu, J.; Predicala, R.Z.; Mangalindan, G.C.; Nesslany, F.; Marzin, D.; Concepcion, G.P.; Diquet, B. Heptyl prodigiosin, a bacterial metabolite, is antimalarial in vivo and non-mutagenic in vitro. J. Nat. Toxins 2002, 11, 367-377.

110. Patil, C.D.; Patil, S.V.; Salunke, B.K.; Salunkhe, R.B. Prodigiosin produced by Serratia marcescens NMCC46 as a mosquito larvicidal agent against Aedes aegypti and Anopheles stephensi. Parasitol. Res. 2011, 109, 1179-1187.

111. Suryawanshi, R.K.; Patil, C.D.; Borase, H.P.; Narkhede, C.P.; Salunke, B.K.; Patil, S.V. Mosquito larvicidal and pupaecidal potential of prodigiosin from Serratia marcescens and understanding its mechanism of action. Pestic. Biochem. Physiol. 2015, 123, 49-55. [CrossRef] [PubMed] 
112. Zhou, W.; Jin, Z.X.; Wan, Y.J. Apoptosis of human lung adenocarcinoma A549 cells induced by prodigiosin analogue obtained from an entomopathogenic bacterium Serratia marcescens. Appl. Microbiol. Biotechnol. 2010, 88, 1269-1275. [CrossRef] [PubMed]

113. Asano, S.; Ogiwara, K.; Nakagawa, Y.; Suzuki, K.; Hori, H.; Watanabe, T. Prodigiosin produced by Serratia marcescens enhances the insecticidal activity of Bacillus thuringiensis deltaendotoxin (Cry 1C) against common cutworm, Spodoptera litura. J. Pestic. Sci. 1999, 24, 381-385. [CrossRef]

114. Campàs, C.; Dalmau, M.; Montaner, B.; Barragan, M.; Bellosillo, B.; Colomer, D.; Pons, G.; Perez-Tomas, R.; Gil, J. Prodigiosin induces apoptosis of B and T cells from B-cell chronic lymphocytic leukemia. Leukemia 2003, 17, 746-750. [CrossRef]

115. Liu, R.; Cui, C.B.; Duan, L.; Gu, Q.Q.; Zhu, W.M. Potent in vitro anticancer activity of metacycloprodigiosin and undecylprodigiosin from a sponge-derived actinomycete Saccharopolyspora sp. nov. Arch. Pharm. Res. 2005, 28, 1341-1344. [CrossRef]

116. Chiu, W.J.; Lin, S.R.; Chen, Y.H.; Tssai, M.J.; Leong, M.K.; Weng, C.F. Prodigiosin-emerged PI3K/Beclin-1-independent pathway elicits autophagic cell death in doxorubicin-sensitive and-resistant lung cancer. J. Clin. Med. 2018, 7, 321. [CrossRef]

117. Cheng, M.F.; Lin, C.S.; Chen, Y.H.; Sung, P.J.; Lin, S.R.; Tong, Y.W.; Weng, C.F. Inhibitory growth of oral squamous cell carcinoma cancer via bacterial prodigiosin. Mar. Drugs 2017, 15, 224. [CrossRef]

118. Lin, S.R.; Weng, C.F. PG-priming enhances doxorubicin influx to trigger necrotic and autophagic cell death in oral squamous cell carcinoma. J. Clin. Med. 2018, 7, 325. [CrossRef] [PubMed]

119. Llagostera, E.; Soto-Cerrato, V.; Joshi, R.; Montaner, B.; Gimenez-Bonafe, P.; Perez-Tomas, R. High cytotoxic sensitivity of the human small cell lung doxorubicin-resistant carcinoma (GLC4/ADR) cell line to prodigiosin through apoptosis activation. Anticancer Drugs 2005, 16, 393-399. [CrossRef] [PubMed]

120. Llagostera, E.; Soto-Cerrato, V.; Montaner, B.; Perez-Tomas, R. Prodigiosin induces apoptosis by acting on mitochondria in human lung cancer cells. Ann. N. Y. Acad. Sci. 2003, 1010, 178-181. [CrossRef] [PubMed]

121. Monge, M.; Vilaseca, M.; Soto-Cerrato, V.; Montaner, B.; Giralt, E.; Perez-Tomas, R. Proteomic analysis of prodigiosin-induced apoptosis in a breast cancer mitoxantrone-resistant (MCF-7 MR) cell line. Investig. New Drugs 2007, 25, 21-29. [CrossRef] [PubMed]

122. Soto-Cerrato, V.; Vinals, F.; Lambert, J.R.; Kelly, J.A.; Perez-Tomas, R. Prodigiosin induces the proapoptotic gene NAG-1 via glycogen synthase kinase-3 $\beta$ activity in human breast cancer cells. Mol. Cancer Ther. 2007, 6, 362-369. [CrossRef] [PubMed]

123. Soto-Cerrato, V.; Llagostera, E.; Montaner, B.; Scheffer, G.L.; Perez-Tomas, R. Mitochondria-mediated apoptosis operating irrespective of multidrug resistance in breast cancer cells by the anticancer agent prodigiosin. Biochem. Pharmacol. 2004, 68, 1345-1352. [CrossRef] [PubMed]

124. Wang, Z.; Li, B.; Zhou, L.; Yu, S.; Su, Z.; Song, J.; Sun, Q.; Sha, O.; Wang, X.; Jiang, W.; et al. Prodigiosin inhibits Wnt/ $\beta$-catenin signaling and exerts anticancer activity in breast cancer cells. Proc. Natl. Acad. Sci. USA 2016, 113, 13150-13155. [CrossRef] [PubMed]

125. Pan, M.Y.; Shen, Y.C.; Lu, C.H.; Yang, S.Y.; Ho, T.F.; Peng, Y.T.; Chang, C.C. Prodigiosin activates endoplasmic reticulum stress cell death pathway in human breast carcinoma cell lines. Toxicol. Appl. Pharmacol. 2012, 265, 325-334. [CrossRef] [PubMed]

126. Lu, C.H.; Lin, S.C.; Yang, S.Y.; Pan, M.Y.; Lin, Y.W.; Hsu, C.Y.; Wei, Y.H.; Chang, J.S.; Chang, C.C. Prodigiosin-induced cytotoxicity involves RAD51 down-regulation through the JNK and p38 MAPK pathways in human breast arcinoma cell lines. Toxicol. Lett. 2012, 212, 83-89. [CrossRef]

127. Ho, T.F.; Peng, Y.T.; Chuang, S.M.; Lin, S.C.; Feng, B.L.; Lu, C.H.; Yu, W.J.; Chang, J.S.; Chang, C.C. Prodigiosin down-regulates survivin to facilitate paclitaxel sensitization in human breast carcinoma cell lines. Toxicol. Appl. Pharmacol. 2009, 235, 253-260. [CrossRef]

128. Hassankhani, R.; Sam, M.R.; Esmaeilou, M.; Ahangar, P. Prodigiosin isolated from cell wall of Serratia marcescens alters expression of apoptosis-related genes and increases apoptosis in colorectal cancer cells. Med. Oncol. 2015, 32, 366. [CrossRef]

129. Dalili, D.; Fouladdel, S.; Rastkari, N.; Samadi, N.; Ahmadkhaniha, R.; Ardavan, A.; Azizi, E. Prodigiosin, the red pigment of Serratia marcescens, shows cytotoxic effects and apoptosis induction in HT-29 and T47D cancer cell lines. Nat. Prod. Res. 2012, 26, 2078-2083.

130. Montaner, B.; Perez-Tomas, R. Prodigiosin-induced apoptosis in human colon cancer cells. Life Sci. 2001, 68, 2025-2036. [CrossRef] 
131. Prabhu, V.V.; Hong, B.; Allen, J.E.; Zhang, S.; Lulla, A.R.; Dicker, D.T.; El-Deiry, W.S. Small molecule prodigiosin restores p53 tumor suppressor activity in chemoresistant colorectal cancer stem cells via c-Jun-mediated DNp73 inhibition and p73 activation. Cancer Res. 2016, 76, 1989-1999. [CrossRef] [PubMed]

132. Castillo-Avila, W.; Abal, M.; Robine, S.; Perez-Tomas, R. Non-apoptotic concentrations of prodigiosin $\left(\mathrm{H}^{+} / \mathrm{Cl}^{-}\right.$ symporter) inhibit the acidification of lysosomes and induce cell cycle blockage in colon cancer cells. Life Sci. 2005, 78, 121-127. [CrossRef] [PubMed]

133. Díaz-Ruiz, C.; Montaner, B.; Pérez-Tomás, R. Prodigiosin induces cell death and morphological changes indicative of apoptosis in gastric cancer cell line HGT-1. Histol. Histopathol. 2001, 16, 415-421. [PubMed]

134. Sam, M.R.; Pourpak, R.S. Regulation of p53 and survivin by prodigiosin compound derived from Serratia marcescens contribute to caspase-3-dependent apoptosis in acute lymphoblastic leukemia cells. Hum. Exp. Toxicol. 2018, 37, 608-617. [CrossRef] [PubMed]

135. Yenkejeh, R.A.; Sam, M.R.; Esmaeillou, M. Targeting survivin with prodigiosin isolated from cell wall of Serratia marcescens induces apoptosis in hepatocellular carcinoma cells. Hum. Exp. Toxicol. 2017, 36, 402-411. [CrossRef]

136. Lund, K.A.R.; Figliola, C.; Kajetanowicz, A.K.; Thompson, A. Synthesis and anticancer activity of prodigiosenes bearing C-ring esters and amides. RSC Adv. 2017, 7, 18617. [CrossRef]

137. Kavitha, R.; Aiswariya, S.; Chandana, R.M. Anticancer activity of red pigment from Serratia marcescens in human cervix carcinoma. Int. J. Pharm. Res. 2010, 2, 784-787.

138. Hong, B.; Prabhu, V.V.; Zhang, S.; van den Heuvel, A.P.; Dicker, D.T.; Kopelovich, L.; El-Deiry, W.S. Prodigiosin rescues deficient p53 signaling and antitumor effects via upregulating p73 and disrupting its interaction with mutant p53. Cancer Res. 2014, 74, 1153-1165. [CrossRef]

139. Pérez-Tomás, R.; Viñas, M. New insights on the antitumoral properties of prodiginines. Curr. Med. Chem. 2010, 17, 2222-2231. [CrossRef]

140. Raj, D.N.; Dhanasekaran, D.; Thajuddin, N.; Panneerselvam, A. Production of prodigiosin from Serratia marcescens and its cytotoxicity activity. J. Pharm. Res. 2009, 2, 590-593.

141. Montaner, B.; Pérez-Tomás, R. The prodigiosins: A new family of anticancer drugs. Curr. Cancer Drug Targets 2003, 3, 57-65. [CrossRef] [PubMed]

142. Montaner, B.; Navarro, S.; Pique, M.; Vilaseca, M.; Martinell, M.; Giralt, E.; Gil, J.; Pérez-Tomás, R. Prodigiosin from the supernatant of Serratia marcescens induce apoptosis in haematopoietic cancer cell line. Br. J. Pharmacol. 2000, 131, 585-593. [CrossRef] [PubMed]

143. Li, D.; Liu, J.; Wang, X.; Kong, D.; Du, W.; Li, H.; Hse, C.Y.; Shupe, T.; Zhou, D.; Zhao, K. Biological potential and mechanism of prodigiosin from Serratia marcescens subsp. lawsoniana in human choriocarcinoma and prostate cancer cell lines. Int. J. Mol. Sci. 2018, 19, 3465. [CrossRef] [PubMed]

144. Elahian, F.; Moghimi, B.; Dinmohammadi, F.; Ghamghami, M.; Hamidi, M.; Mirzaei, S.A. The anticancer agent prodigiosin is not a multidrug resistance protein substrate. DNA Cell Biol. 2013, 32, 90-97. [CrossRef] [PubMed]

145. Muthukumar, A.; Pradeep, P.; Thigale, I.; Mohanasrinivasan, V.; Jemimah, N.S.; Devi, C.S. Exploring the bioactive potential of Serriatia marcescens VITAPI (Acc: 1933637) isolated from soil. Front. Biol. 2016, 11, 476-480. [CrossRef]

146. Abdelfattah, A.S.; Elmallah, M.I.Y.; Ebrahim, H.Y.; Almeer, R.S.; Eltanamy, R.M.A.; Moneim, A.E.A. Prodigiosins from a marine sponge-associated actinomycete attenuate $\mathrm{HCl} / \mathrm{ethanol-induced} \mathrm{gastric} \mathrm{lesion}$ via antioxidant and anti-inflammatory mechanisms. PLoS ONE 2019, 14, e0216737. [CrossRef] [PubMed]

147. Williamson, N.R.; Fineran, P.C.; Gristwood, T.; Chawrai, S.R.; Leeper, F.J.; Salmond, G.P. Anticancer and immunosuppressive properties of bacterial prodiginines. Future Microbiol. 2007, 2, 605-618. [CrossRef]

148. Kim, D.; Kim, J.F.; Yim, J.H.; Kwon, S.K.; Lee, C.H. Red to red- the marine bacterium Hahella chejuensis and its product prodigiosin for mitigation of harmful algal blooms. J. Microbiol. Biotechnol. 2008, 18, 1621-1629.

149. Nakashima, T.; Miyazaki, Y.; Matsuyama, Y.; Muraoka, W.; Yamaguchi, K.; Oda, T. Producing mechanism of an algicidal compound against red tide phytoplankton in a marine bacterium gamma-proteobacterium. Appl. Microbiol. Biotechnol. 2006, 73, 684-690. [CrossRef] [PubMed]

150. Wang, F.; Wei, H.Y.; Li, X.Q.; Li, Y.H.; Li, X.B.; Yin, L.H.; Pu, Y.P. Isolation and characterization of an algicidal bacterium indigenous to Lake Taihu with a red pigment able to lyse Microcystis aeruginosa. Biomed. Environ. Sci. 2013, 26, 148-154. 
151. Gong, J.; Liu, J.; Tan, X.; Li, Z.; Li, Q.; Zhang, J. Bio-preparation and regulation of pyrrole structure nano-pigment based on biomimetic membrane. Nanomaterial 2019, 9, 114. [CrossRef] [PubMed]

152. Chauhan, K.; Dalsaniya, P.; Pathak, H. Optimization of prodigiosin-type biochrome production and effect of mordants on textile dyeing to improve dye fastness. Fiber Polym. 2015, 16, 802-808. [CrossRef]

153. Krishana, J.G.; Jacob, A.; Kurian, P.; Elyas, K.; Muthusamy, C. Marine bacterial prodigiosin as dye for rubber latex, polymethyl methacrylate sheets and paper. Afr. J. Biotechnol. 2013, 12, 2266-2269.

154. Siva, R.; Subha, K.; Bhakta, D.; Ghosh, A.R.; Babu, S. Characterization and ehanced production of prodigiosin from the spoiled coconut. Appl. Biochem. Biotechnol. 2012, 166, 187-196. [CrossRef]

155. Mehta, M.; Shah, G. Extraction of pigent from Serratia marcescens and its application in candle industry. Adv. Appl. Res. 2015, 7, 1-4. [CrossRef]

156. Yip, C.H.; Yarkoni, O.; Ajioka, J.W.; Wan, K.L.; Nathan, S. Recent advancements in high-level synthesis of the promising clinical drug, prodigiosin. Appl. Microbiol. Biotechnol. 2019, 103, 1667-1680. [CrossRef]

157. Hu, D.X.; Withall, D.M.; Challis, G.L.; Thomson, R.J. Structure, chemical synthesis, and biosynthesis of prodiginine natural products. Chem. Rev. 2016, 116, 7818-7853. [CrossRef]

158. Nisha, N.; Kumar, K.; Kumar, V. Prodigiosin alkaloids: Recent advancements in total synthesis and their biological potential. RSC Adv. 2015, 5, 10899-10920. [CrossRef]

159. Stankovic, N.; Senerovic, L.; Ilic-Tomic, T.; Vasiljevic, B.; Nikodinovic-Runic, J. Properties and appications of undecylprodigiosin and other bacterial prodigiosins. Appl. Microbiol. Biotechnol. 2014, 98, 3841-3858. [CrossRef]

160. Williamson, N.R.; Fineran, P.C.; Leeper, F.J.; Salmond, G.P.C. The biosynthesis and regulation of bacterial prodiginines. Nat. Rev. 2006, 4, 887-899. [CrossRef]

161. Andreyeva, I.N.; Ogorodnikova, T.I. Pigmentation of Serratia marcescens and special properties of prodigiosin. Microbiology 2015, 84, 28-33. [CrossRef]

162. Khanafari, A.; Assadi, M.M.; Fakhr, F.A. Review of prodigiosin, pigmentation in Serratia marcescens. J. Biol. Sci. 2006, 6, 1-13. [CrossRef]

163. Hubbard, R.; Rimington, C. The biosynthesis of prodigiosin, the tripyrrylmethane pigment from Bacillus prodigiosus (Serratia marcescens). Biochem. J. 1950, 46, 220-225. [CrossRef] [PubMed]

164. Wasserman, H.H.; Mckeon, J.E.; Smith, L.; Forgione, P. Prodigiosin structure and partial synthesis. J. Am. Chem. Soc. 1960, 82, 506-507. [CrossRef]

165. Rapoport, H.; Holden, K.G. The synthesis of prodigiosin. J. Am. Chem. Soc. 1962, 82, 5510-5511. [CrossRef]

166. Araújo, H.W.C.; Andrade, R.F.S.; Montero-Rodríguez, D.; Rubio-Ribeaux, D.; Alves da Silva, C.A.; Campos-Takaki, G.M. Sustainable biosurfactant produced by Serratia marcescens UCP 1549 and its suitability for agricultural and marine bioremediation applications. Microb. Cell Factories 2019, 18, 2. [CrossRef]

167. Wang, Y.; Zhao, K. Progress in microbial production of prodigiosin. J. Biol. Med. Sci. 2018, 2, 109.

168. Venil, C.K.; Lakshmanaperumalsamy, P. An insightful overview on microbial pigment, prodigiosin. Electron. J. Biol. 2009, 5, 49-61.

169. Kurbanoglu, E.B.; Ozdal, M.; Ozdal, O.G.; Algur, O.F. Enhanced production of prodigiosin by Serratia marcescens MO-1 using ram horn peptone. Braz. J. Microbiol. 2015, 46, 631-637. [CrossRef]

170. Suryawanshi, R.K.; Patil, C.D.; Borase, H.P.; Salinke, B.K.; Patil, S.V. Studies on production and biological potential of prodigiosin by Serratia marcescens. Appl. Biochem. Biotechnol. 2014, 173, 1209-1221. [CrossRef]

171. Chen, W.C.; Yu, W.J.; Chang, C.C.; Chang, J.S.; Huang, S.H.; Chang, C.H.; Chen, S.Y.; Chien, C.C.; Yao, C.L.; Chen, W.M.; et al. Enhancing production of prodigiosin from Serratia marcescens C3 by statistical experimental design and porous carrier addition strategy. Biochem. Eng. J. 2013, 78, 93-100. [CrossRef]

172. Kamble, K.D.; Hiwarale, V.D. Prodigiosin production from Serratia marcescens strains obtained from farm soil. Int. J. Environm. Sci. 2012, 3, 631-638.

173. Araújo, H.W.C.; Fukushima, K.; Takaki, G.M.C. Prodigiosin production by Serratia marcescens UCP1549 using renewable-resources as a low cost substrate. Molecules 2010, 15, 6931-6940. [CrossRef] [PubMed]

174. Bennett, J.; Bentley, R. Seeing red: The story of prodigiosin. Adv. Appl. Microbiol. 2000, 47, 1-32. [PubMed]

175. Wei, Y.H.; Chen, W.C. Enhanced production of prodigiosin-like pigment from Serratia marcescens $\mathrm{SM} \triangle \mathrm{R}$ by medium improvement and oil-supplement strategies. J. Biosci. Bioeng. 2005, 99, 616-622. [CrossRef]

176. Wei, Y.H.; Yu, W.J.; Chen, W.C. Enhanced undecylprodigiosin production from Serratia marcescens SS-1 by medium formulation and amino-acid supplementation. J. Biosci. Bioeng. 2005, 100, 466-471. [CrossRef]

177. Shaikh, Z. Biosynthesis of prodigiosin and its applications. IOSR J. Pharm. Biol. Sci. 2016, 11, 1-28. 
178. Gerber, N.N.; Gauthier, M.J. New prodigiosin-like pigment from Alteromonas rubra. Appl. Environ. Microbiol. 1979, 37, 1176-1179. [CrossRef]

179. Schloss, P.D.; Allen, H.K.; Klimowicz, A.K.; Mlot, C.; Gross, J.A.; Savengsuksa, S.; McEllin, J.; Clardy, J.; Ruess, R.W.; Handelsman, J. Psychrotrophic strain of Janthinobacterium lividum from a cold Alaskan soil produces prodigiosin. DNA Cell Biol. 2010, 29, 533-541. [CrossRef]

180. Darshan, N.; Manonmani, H.K. Prodigiosin and its potential applications. J. Food Sci. Technol. 2015, 52, 5393-5407. [CrossRef]

181. Gerber, N.N.; Stahly, D.P. Prodiginine (prodigiosin-like) pigments from Streptoverticillium rubrireticuli, an organism that causes pink staining of polyvinyl chloride. Appl. Microbiol. 1975, 30, 807-810. [CrossRef] [PubMed]

182. Liu, P.; Zhu, H.; Zheng, G.; Jiang, W.; Lu, Y. Metabolic engineering of Streptomyces coelicolor for enhanced prodigiosins (RED) production. Sci. China Life Sci. 2017, 60, 948-957. [CrossRef] [PubMed]

183. Alihosseini, F.; Lango, J.; Ju, K.S.; Hammock, B.D.; Sun, G. Mutation of bacterium Vibrio gazogenes for selective preparation of colorants. Biotechnol. Prog. 2010, 26, 352-360. [PubMed]

184. D'Aoust, J.Y.; Gerber, N.N. Isolation and purification of prodigiosin from Vibrio psychroerythrus. J. Bacteriol. 1974, 118, 756-757. [CrossRef]

185. Gandhi, N.M.; Patell, J.R.; Gandhi, J.; De Souza, N.J.; Kohl, H. Prodigiosin metabolites of a marine Pseudomonas species. Mar. Biol. 1976, 34, 223-227. [CrossRef]

186. Sakai-Kawada, F.E.; Ip, C.G.; Hagiwara, K.A.; Awaya, J.D. Biosynthesis and bioactivity of prodiginine analogs in marine bacteria, Pseudoalteromonas: A mini review. Front. Microbiol. 2019, 10, 1715. [CrossRef]

187. Perry, J.J. Prodigiosin in an actinomycete. Nature 1961, 1, 77-78. [CrossRef]

188. Domröse, A.; Klein, A.S.; Hage-Hülsmann, J.; Thies, S.; Svensson, V.; Classen, T.; Pietruszka, J.; Jaeger, K.E.; Drepper, T.; Loeschcke, A. Efficient recombinant production of prodigiosin in Pseudomonas putida. Front. Microbiol. 2015, 6, 972. [CrossRef]

189. Klein, A.S.; Domröse, A.; Bongen, P.; Brass, H.U.C.; Classen, T.; Loeschcke, A.; Drepper, T.; Laraia, L.; Sievers, S.; Jaeger, K.E.; et al. New prodigiosin derivatives obtained by mutasynthesis in Pseudomonas putida. ACS Synth. Biol. 2017, 6, 1757-1765. [CrossRef]

190. Cang, S.; Sanada, M.; Johdo, O.; Ohta, S.; Nagamatsu, Y.; Yoshimoto, A. High production of prodigiosin by Serratia marcescens grown on ethanol. Biotechnol. Lett. 2000, 22, 1761-1765. [CrossRef]

191. Gerber, N.N.; Lechevalier, M.P. Prodiginine (prodigiosin-like) pigments from Streptomyces and other aerobic Actinomycetes. Can. J. Microbiol. 1976, 22, 658-667. [CrossRef] [PubMed]

192. Loriia, Z.h.K.; Briukner, B.; Egorov, N.S. Correlation between the synthesis of extracellular proteases and the synthesis of the red pigment prodigiosin in Serratia marcescens. Mikrobiology 1977, 46, 647-650.

193. Loriia, Zh.K.; Briukner, B.; Egorov, N.S. Effect of amino acids on the synthesis of extracellular protease in Serratia marcescens. Mikrobiology 1977, 46, 41-45.

194. Loriia, Zh.K.; Briukner, B.; Ezorov, N.S. The effect of glucose on induced synthesis of exocellular protease of Serratia marcescens. Mikrobiology 1977, 46, 926-930.

195. Cruz Camarillo, R.; Albores Medina, A. Obtainment of extracellular alkaline protease from Serratia marcescens for commercial purposes. Rev. Latinoam. Microbiol. 1972, 14, 211-219. [PubMed]

196. Alves, T.S.; Salgado, J.P.; Andrade, R.F.S.; Montero-Rodríguez, D.; Ferreira, W.B.; Almeida, M.M.; Campos-Takaki, G.M.; Araújo, H.W.C. Production and evaluation of biosurfactant by Serratia marcescens UCP 1549 using industrial wastes. Br. Biotechnol. J. 2014, 4, 708-719. [CrossRef]

197. Wei, Y.H.; Lai, H.C.; Chen, S.Y.; Yeh, M.S.; Chang, J.S. Characterization of biosurfactant production by Serratia marcescens SS-1 and its isogenic strain SM $\delta$ R defective in spnR, a quorum sensing LuxR familiy protein. Biotechnol. Lett. 2004, 26, 799-802. [CrossRef]

198. Santos, D.K.; Rufino, R.D.; Luna, J.M.; Santos, V.A.; Sarubbo, L.A. Biosurfactants: Multifunctional biomolecules of the 21st century. Int. J. Mol. Sci. 2016, 17, 401. [CrossRef]

199. Solé, M.; Rius, N.; Francia, A.; Lorén, J.G. The effect of $\mathrm{pH}$ on prodigiosin production by non-proliferating cells of Serratia marcescens. Lett. Appl. Microbiol. 1994, 19, 341-344. [CrossRef]

200. Rjazantseva, I.N.; Andreeva, I.N.; Ogorodnikova, T.I. Effect of various growth conditions on pigmentation of Serratia marcescens. Microbios 1994, 79, 155-161. 
201. Giri, A.V.; Anandkumar, N.; Muthukumaran, G.; Pennathur, G. A novel medium for the enhanced cell growth and production of prodigiosin from Serratia marcescens isolated from soil. BMC Microbiol. 2004, 4, 11. [CrossRef] [PubMed]

202. Elkenawy, N.M.; Yassin, A.S.; Elhifnawy, H.N.; Amin, M.A. Optimization of prodigiosin production by Serratia marcescens using crude glycerol and enhancing production using gamma radiation. Biotechnol. Rep. (Amst.) 2017, 14, 47-53. [CrossRef] [PubMed]

203. Williamson, N.R.; Simonsen, H.T.; Ahmed, R.A.; Goldet, G.; Slater, H.; Woodley, L.; Leeper, F.J.; Salmond, G.P. Biosynthesis of the red antibiotic, prodigiosin, in Serratia: Identification of a novel 2-methyl-3-n-amyl-pyrrole (MAP) assembly pathway, definition of the terminal condensing enzyme, and implications for undecylprodigiosin biosynthesis in Streptomyces. Mol. Microbiol. 2005, 56, 971-989. [CrossRef] [PubMed]

204. Couturier, M.; Bhalara, H.D.; Chawrai, S.R.; Monson, R.; Williamson, N.R.; Salmond, G.P.C.; Leeper, F.J. Substrate flexibility of the flavin-dependent dihydropyrrole oxidases PigB and HapB involved in antibiotic prodigiosin biosynthesis. ChemBioChem 2020, 21, 523-530. [CrossRef]

205. Lou, X.; Ran, T.; Han, N.; Gao, Y.; He, J.; Tang, L.; Xu, D.; Wang, W. Crystal structure of the catalytic domain of PigE: A transaminase involved in the biosynthesis of 2-methyl-3- $n$-amyl-pyrrole (MAP) from Serratia sp. FS14. Biochem. Biophys. Res. Commun. 2014, 447, 178-183. [CrossRef]

206. Song, M.J.; Bae, J.; Lee, D.S.; Kim, C.H.; Kim, J.S.; Kim, S.W.; Hong, S.I. Purification and characterization of prodigiosin produced by integrated bioreactor from Serratia sp. KH-95. J. Biosci. Bioeng. 2006, 101, 157-161. [CrossRef] [PubMed]

207. Juang, R.S.; Yeh, C.L. Adsorptive recovery and purification of prodigiosin from methanol/water solutions of Serratia marcescens fermentation broth. Biotechnol. Bioproc. Eng. 2014, 19, 159-168. [CrossRef]

208. Wang, X.; Tao, J.; Wei, D.; Shen, Y.; Tong, W. Development of an adsorption procedure for the direct separation and purification of prodigiosin from culture broth. Biotechnol. Appl. Biochem. 2004, 40, 277-280.

209. Khanam, B.; Chandra, R. Comparative analysis of prodigiosin isolated from endophyte Serratia marcescens. Lett. Appl. Microbiol. 2018, 66, 194-201. [CrossRef]

210. Liu, X.; Wang, Y.; Sun, S.; Zhu, C.; Xu, W.; Park, Y.; Zhou, H. Mutant breeding of Serratia marcescens strain for enhancing prodigiosin production and application to textiles. Prepar. Biochem. Biotechnol. 2013, 43, 271-284. [CrossRef]

211. Vaidyanathan, J.; Bhathena-Langdana, Z.; Adivarekar, R.V.; Nerurkar, M. Production, partial characterization, and use of a red biochrome produced by Serratia sakuensis subsp. nov. strain KRED for dyeing natural fibers. Appl. Biochem. Biotechnol. 2012, 166, 321-335. [CrossRef]

212. Lin, C.; Jia, X.; Fang, Y.; Chen, L.; Zhang, H.; Lin, R.; Chen, J. Enhanced production of prodigiosin by Serratia marcescens FZSF02 in the form of pigment pellets. Electron. J. Biotechnol. 2019, 40, 58-64. [CrossRef]

213. Hazarika, D.J.; Gautom, T.; Parveen, A.; Goswami, G.; Barooah, M.; Modi, M.K.; Boro, R.C. Mechanism of interaction of an endofungal bacterium Serratia marcescens D1 with its host and non-host fungi. PLoS ONE 2020, 15, e0224051. [CrossRef] [PubMed]

214. Liu, P.; Wang, Y.Y.; Qi, X.; Gu, Q.; Geng, M.; Li, J. Undecylprodigiosin induced apoptosis in P388 cancer cells is associated with its binding to ribosome. PLoS ONE 2013, 8, e65381. [CrossRef] [PubMed]

(C) 2020 by the authors. Licensee MDPI, Basel, Switzerland. This article is an open access article distributed under the terms and conditions of the Creative Commons Attribution (CC BY) license (http://creativecommons.org/licenses/by/4.0/). 